MATUS, Jean Pierre. "Acerca de la actual falta de punibilidad en Chile de los acuerdos de precios".

Polít. crim. Vol. 7, No 14 (Diciembre 2012), Art. 3, pp. 318 - 356.

[http://www.politicacriminal.cl/Vol_07/n_14/Vol7N14A3.pdf]

\title{
Acerca de la actual falta de punibilidad en Chile de los acuerdos de precios"
}

\author{
Dr. Jean Pierre Matus \\ Profesor Titular de Derecho Penal de la Universidad de Chile \\ jpmatus@derecho.uchile.cl
}

\section{Resumen}

El artículo demuestra que los acuerdos de precios entre oferentes de bienes de consumo no son punibles actualmente en Chile, según la correcta interpretación de las normas que se han invocado para ello, los artículos 285 y 473 del Código penal, y la evolución histórica de la regulación de los atentados contra la libre competencia, entregada hoy día exclusivamente a la sede administrativa y a un tribunal especial creado al efecto. Al mismo tiempo, se demuestra que las reglas del concurso aparente de leyes no pueden invocarse para sostener el "resurgimiento" de normas que habrían sido expresa o tácitamente derogadas, sin infracción de la garantía del principio de legalidad, que supone la aplicación de leyes vigentes al momento de la perpetración de los delitos.

\section{Palabras clave}

Acuerdos de precios, delitos contra la libre competencia, derogación.

\begin{abstract}
The paper shows that price agreements between suppliers of consumer goods are not currently punishable in Chile, according to the correct interpretation of the rules that have been invoked to that end, Articles 285 and 473 of the Criminal Code, and the historical evolution of the regulation and punishment of offenses against free competition, today delivered exclusively to the administrative authority and a special court created for that purpose. At the same time, it is shown that the principle that a general law can be applied when the special law is repealed, it can be argued that when previously general law (or the relevant part) has been repealed because it would mean a violation of the guarantee of the principle of legality, which involves the application of existing laws at the time of commission of the offenses.
\end{abstract}

\section{Key words}

Price agreements, crimes against free competition, repeal.

\footnotetext{
* El contenido de este artículo es una versión reelaborada y revisada del Informe en Derecho que he preparado para los representantes de una de las cadenas de farmacias que en Chile se encuentran actualmente bajo investigación criminal. No obstante lo anterior, en él se recoge mi opinión científica, fundada en la interpretación que estimo conforme a Derecho de las normas que se analizan, y no una defensa de parte.
} 
MATUS, Jean Pierre. “Acerca de la actual falta de punibilidad en Chile de los acuerdos de precios".

\section{Introducción}

La reciente derogación de las disposiciones penales del Decreto Ley $\mathrm{N}^{\mathrm{o}} 211$ por parte de la Ley N ${ }^{\circ} 19.911$, de 14 de noviembre de 2003, cuyo propósito declarado en el punto "III.3." del Mensaje Presidencial que le dio origen fue la "eliminación del carácter penal" de las infracciones a la libre competencia, "que rara vez ha dado paso a la acción penal y se estima que no ha logrado disuadir las conductas contrarias a la libre competencia", 1 y su reemplazo por sanciones de carácter administrativo, ha traído entre nosotros la cuestión acerca de si los acuerdos de precios, ahora sancionados administrativamente, podrían eventualmente, además, ser castigados como delitos, de conformidad con lo dispuesto en los artículos 285 y 473 del Código penal.

Esta cuestión ofrece dos problemas relevantes que pueden ser analizados desde el punto de vista penal: primero, si es efectivo que los acuerdos de precios pueden ser subsumibles en las disposiciones de los artículos 285 y 473 del Código penal; y en segundo lugar, de admitirse que así sea, si ello no supondría una infracción al principio ne bis in ídem, atendido el hecho de que la sanción administrativa que se establece para estos mismos supuestos es cuantiosa y se impone por un tribunal especial cuyo fiscal tiene atribuciones similares a las del Ministerio Público (puede solicitar allanamientos e interceptaciones telefónicas, entre otras medidas intrusivas de investigación).

De estos dos problemas, en este texto se abordará sólo el primero, dado que para el planteamiento del segundo se debe haber llegado previamente a una conclusión respecto de éste. Para ello, estudiaremos en primer lugar el sentido y alcance del Artículo 285 del Código penal; luego, la posibilidad de subsumir tales hechos en la figura del Artículo 473 del Código penal; a continuación, el sentido y alcance (en materia penal) de la regulación especial acerca de la libre competencia, a partir de la primera ley en la materia, la $\mathrm{N}^{\mathrm{o}}$ 13.305, de 6 de abril de 1959 y sus modificaciones posteriores y sus posibilidades de interpretación; $\mathrm{y}$ antes de concluir, analizaremos las propuestas legislativas $\mathrm{y}$ modificaciones posteriores a la entrada en vigencia de la Ley $\mathrm{N}^{\mathrm{0}} 19.91$, de 2003, que vino a despenalizar las figuras entes contempladas en la legislación especial en la materia. Especial referencia se hará, por su importancia en el tema, a la historia del establecimiento de las disposiciones penales en juego ya las cuestiones vinculadas respectos a los efectos derogatorios y la teoría del concurso aparente de leyes, a propósito de las disposiciones derogatorias de la Ley $\mathrm{N}^{\mathrm{o}} 13.305$.

\section{Sentido y alcance del Artículo 285 del Código penal.}

Como señala don Eduardo Novoa, en el Código de 1874, el Artículo 285 del Código penal es una de las escasísimas disposiciones originales de dicho cuerpo normativo que regulan, junto con el delito de usura, un delito económico propiamente tal. ${ }^{2}$

\footnotetext{
${ }^{1}$ BIBLIOTECA DEL CONGRESO NACIONAL. Historia de la Ley $N^{\circ}$ 19.911, Crea el Tribunal de Defensa de la Libre Competencia. 14 de noviembre de 2003, 669 pp., p. 12.

${ }^{2}$ NOVOA MONREAL, Eduardo, "La legislación penal económica", en: UNIVERSIDAD CATÓLICA DE CHILE. FACULTAD DE CIENCIAS JURÍDICAS, POLÍTICAS Y SOCIALES. La Nueva Legislación y el
} 
Polít. crim. Vol. 7, No 14 (Diciembre 2012), Art. 3, pp. 318 - 356.

[http://www.politicacriminal.cl/Vol_07/n_14/Vol7N14A3.pdf]

Dicho artículo castiga penalmente a los que "por medios fraudulentos consiguieren alterar el precio natural de del trabajo, de los géneros o mercaderías, acciones, rentas públicas o privadas o de cualesquiera otras cosas que fueren objeto de su contratación".

\subsection{Orígenes: los artículos 461 y 462 del Código penal español de 1850 (450 y 451 Código penal de 1848).}

A partir de la mención que a ellos hacen la Comisión Redactora y los primeros comentaristas patrios, se suele afirmar entre nosotros que el origen del artículo 285 de nuestro Código penal se encuentra en los artículos 461 y 462 del Código penal español de 1850. ${ }^{3}$ Sin embargo, estas son las mismas disposiciones contempladas en los artículos 450 y 451 del Código español de 1848, cuyas concordancias refiere Pacheco, según el texto tenido a la vista, a la Ley 2, Titulo 7, Partida V, que castigaba con destierro, comiso y una multa a favor del Rey el "coto" que ponían los acuerdos de precios de mercaderías y del trabajo no autorizados por éste; a los artículos 414 a 419 del Código francés de 1810, y a las disposiciones de los artículos 227 a 229 del Código austríaco. ${ }^{4}$

Si se analizan las disposiciones a las que se remiten las concordancias, descontado el régimen de las Partidas, su principal particularidad es que en ellas se hacía una distinción más o menos clara entre tres conductas diferentes: los acuerdos o "coligaciones" para determinar el precio del trabajo (tanto por empleadores como por trabajadores); la "coligaciones" para fijar el precio de las mercaderías; y el empleo de medios fraudulentos para alterar el precio de las mercaderías que resultaría de la libre concurrencia.

Así, según transcribe el citado Pacheco, el Código francés castigaba separadamente la "coligación" "entre los que tengan trabajadores a su servicio" (artículo 414), de la realizada por los propios trabajadores (artículo 416); y ambas de "la coligación entre los principales tenedores de una misma mercancía o artículo formada para no venderla, o venderla solo a cierto precio" (artículo 419), la cual se penaba en conjunto con la divulgación de hechos falsos y la actuación "por otras vías o medios fraudulentos", que "hicieren subir o bajar el precio de géneros, mercancías, documentos o efectos públicos, en más o menos suma de la que hubiere resultado de la libre concurrencia del comercio". Por su parte, aunque el Código austríaco describía como "infracción de policía" en un solo artículo "el concierto entre algunos o todos los individuos de una profesión para hacer subir o bajar en provecho propio y en perjuicio del público el precio de una mercancía o trabajo" (artículo 227, parte final), castigaba con diferentes penas las "coligaciones de obreros artesanos" (artículo 229), de las restantes (artículo 228).

Sin embargo, al redactarse el Código español de 1848, de los tres casos previstos en las legislaciones que sirvieron de antecedente, esto es, la coligación para fijar los precios del

Desarrollo Económico de Chile. Ciclo de Conferencias, Julio-Septiembre, 1962. Santiago: Editorial Universidad Católica, 1962, 179 pp., pp. 151-177,p. 154.

${ }^{3}$ Ver, por todos, FUENZALIDA, Alejandro, Concordancias i Comentarios del Código penal chileno, t. III. Lima: Imp. Comercial Calle del Haullaga N. 139, 1883, 372 pp., p. 300.

${ }^{4}$ PACHECO, Joaquín Francisco, El Código penal concordado y comentado, t. III, Madrid: Imp. Santiago Saunaque, 1849, 500 pp., pp. 384 y ss. 
MATUS, Jean Pierre. “Acerca de la actual falta de punibilidad en Chile de los acuerdos de precios".

trabajo, la coligación para fijar los precios de las mercaderías, y el empleo de medios fraudulentos para alterar su precio natural (el que resulta de la libre concurrencia), sólo aparecieron expresamente recogidos el primero y el último.

En efecto, mientras el artículo 450 del texto hispano castigaba a "los que se coaligaren con el fin de encarecer o abaratar abusivamente el precio del trabajo, o regular sus condiciones"; el 451 lo hacía respecto de "los que esparciendo falsos rumores, ó usando de cualquier otro artificio, consiguieren alterar los precios naturales que resultarían de la libre concurrencia en las mercaderías, acciones, rentas públicas ó privadas, ó cualesquiera otras cosas que fueren objeto de contratación".

Por lo mismo, omite mencionar Pacheco en sus Comentarios la posibilidad de que el artículo 451 contemplase también la "coligación efectiva" para fijar los precios de las mercaderías diferentes al trabajo, esto es, la "resolución, acuerdo, concurrencia de varias personas para ello", como lo requería para configurar el delito del artículo 450. En cambio, comenta el artículo 451, limitando su alcance explícitamente a los medios fraudulentos a que allí se señalan ("esparciendo falsos rumores, o usando cualquier otro artificio"): "una carta falsa leída en la Bolsa, un posta simulado que se haga entrar ostensiblemente para divulgar cierta noticia, un anuncio hábil inserto en un periódico, pueden en determinadas circunstancias causar un trastorno en los precios, que enriquezca y arruine a mil á mil personas."

Por lo tanto, ya en el texto hispano tomado como modelo por nuestra Comisión Redactora se había excluido la tipificación como delito del caso de la "coligación" para fijar precios de las mercaderías, entonces comprendido expresamente en los Códigos francés y austríaco que le sirvieron de antecedente, quedando únicamente como figura delictiva las llamadas "maquinaciones para alterar el precio de las cosas", consistentes en la difusión de rumores falsos o el empleo de cualquier otro artificio fraudulento con ese propósito. De hecho, el nuevo Código penal de 1995, no deroga esta figura ni la amplía incorporando nuevamente la "coligación" para fijar los precios, sino que "concreta las conductas tipificadas a diferencia de lo que hacía el C.p. derogado, como son la difusión de noticias falsas, empleando violencia, amenaza o engaño", 6 ninguna de las cuales es equivalente a la "coligación" o acuerdo de precios. ${ }^{7}$

\footnotetext{
${ }^{5}$ PACHECO, Código penal, cit. nota ${ }^{\circ} 4$, p. 387.

${ }^{6}$ SERRANO GÓMEZ, Alfonso; SERRANO MAÍLLO, Alfonso. Derecho penal, parte especial, $12^{a}$ edición. Madrid: Dykinson 2007, 1186 pp., p. 513. El actual artículo 284 del Código penal español de 1995 castiga "a los que, difundiendo noticias falsas, empleando violencia, amenaza o engaño, o utilizando información privilegiada, intentaren alterar los precios que habrían de resultar de la libre concurrencia de productos, mercancías, títulos valores, servicios o cualesquiera otras cosas muebles o inmuebles que sean objeto de contratación, sin perjuicio de la pena que pudiera corresponderles por otros delitos cometidos".

7 Esto explica por qué la literatura española nunca consideró los acuerdos de precio dentro de la figura comentada: no se trata de un "interpretación restrictiva", sino del auténtico sentido de la disposición que, apartándose del modelo francés, excluyó entre sus hipótesis comisivas el acuerdo de precios y sólo mantuvo el fraude para su fijación.
} 
Polít. crim. Vol. 7, No 14 (Diciembre 2012), Art. 3, pp. 318 - 356.

[http://www.politicacriminal.cl/Vol_07/n_14/Vol7N14A3.pdf]

\subsection{La discusión en la Comisión Redactora del Código penal de 1874: supresión de toda "coligación" no fraudulenta para fijar precios como hecho punible.}

A pesar de que en el antecedente español es claro que no se sancionaba penalmente los acuerdos de precios entre productores, caso diferente al de los fraudes para alterarlos, algunos han sostenido que la Comisión Redactora de nuestro Código penal, al no expresar determinadamente las formas de estos fraudes, habría ampliado la figura del Código español, permitiendo que se consideraran los acuerdos de precios dentro de una idea más o menos genérica de medios fraudulentos para alterar los precios.

Sin embargo, para llegar a esta conclusión se debe suponer en los redactores del Código una intención completamente diferente a la que tuvieron. Primero, porque como ya no se encontraban los acuerdos de precios sancionados en el Código penal que tuvieron de modelo, es muy difícil sostener que quisieran nuevamente castigarlos, sin ninguna mención expresa de ello, teniendo a mano la posibilidad de copiar el texto del Código francés o del austríaco, como aparecían reproducidos en el Comentario de Pacheco que tenían a la vista. No hay, en efecto, ninguna referencia en las Actas que permita concluir que la intención de los comisionados o el alcance del término que emplearon ("medios fraudulentos") incluyera los "acuerdos de precios", expresamente señalados en el Código francés como un caso diferente al del fraude $\mathrm{y}$, también como un caso diferente al de las coaligaciones de trabajores y empleadores.

Como señala Fuenzalida, "en la primera redacción del proyecto de nuestro código se había aprobado un artículo que penaba, como el 461 del Código Español [de 1850, 450 del Código de 1848], a la coligaciones para encarecer o abaratar abusivamente el precio del trabajo o regular sus condiciones". 8

En la misma sesión en que se aprobó dicho artículo ( $\mathrm{N}^{\mathrm{o}}$ 61, de 13 de octubre de 1871), se tomó, "con alguna modificación en cuanto a la pena", y también en la redacción (pero sin hacer mención expresa del por qué), del artículo 462 Código penal español de 1850 [451 del texto de 1848] la primera redacción del que llegaría a ser nuestro actual artículo 285, entonces numerado como 276 en el Proyecto:

“Artículo 276. Los que por cualesquiera medios fraudulentos consiguieren alterar el precio natural de los jéneros, mercancías, acciones, rentas públicas o privadas, o cualesquiera otras cosas que fueren objeto de contratación, sufrirán las penas de reclusión menor i multa". 10

\footnotetext{
${ }^{8}$ FUENZALIDA, Concordancias, cit. nota $\mathrm{n}^{\circ}$ 3, p. 300. Por un error de transcripción, en el texto de Fuenzalida se cita esta Sesión como la No 61, de doce de octubre de 1871. Sin embargo, teniendo a la vista el texto original de las Actas, puede leerse que la sesión en cuestión parece fechada el día trece de ese mes: Actas de las sesiones de la Comisión Redactora del Código penal chileno. Santiago: Imp. De la República de Jacinto Nuñez, 1873, 314 pp. encuadernadas junto al Proyecto de Código penal Chileno, de la misma imprenta y año, p. 119.

${ }^{9}$ FERNÁNDEZ, Pedro Javier, Código penal de la República de Chile, explicado i concordado. Segunda Edición notablemente aumentada i corregida, t. II, Santiago: Imp. Barcelona, 1900, 410 pp., p. 33.

${ }^{10}$ Actas, cit. nota ${ }^{\circ} 8$, p. 120.
} 
MATUS, Jean Pierre. “Acerca de la actual falta de punibilidad en Chile de los acuerdos de precios".

Y, además, se aprobó, sin mayor discusión, la figura agravada del entonces proyectado artículo 277 y que hoy corresponde al artículo 286 del vigente Código penal. Esta figura agravada contemplaba dos incisos, en el primero de los cuales se reafirmaba el carácter fraudulento de las conductas sancionados en la figura general, agregando el segundo, sin embargo, una disposición particular en la cual parecía asimilarse la "coalición" fraudulenta para fijar precios con alguno de los medios fraudulentos de que hablaba la disposición general. Así, este entonces proyectado artículo 277 disponía:

“Artículo 277. Cuando el fraude espresado en el artículo anterior recayere sobre mantenimientos u otros objetos de primera necesidad, ademas de las penas que en él se señalan, se impondrá la de comiso de los jéneros que fueren objeto del fraude.

Para la imposición de estas penas, bastará que la coalición haya empezado a ejecutarse."

Comentado la idéntica disposición contemplada en el artículo 452 del Código penal español de 1848, Pacheco aclara su sentido, al afirmar que "el caso de este artículo es cuando los dueños de los efectos en cuestión fueren los autores del fraude, con el objeto de elevar el precio." 11 Es decir, se trataría del caso de una "coligación" fraudulenta ("los autores del fraude"), para "elevar el precio" de mercaderías esenciales.

De este modo, se reproducía en el entonces proyectado Código una situación idéntica a la del Código español de 1848, esto es, el castigo de sólo dos de los tres supuestos comprendidos en los códigos francés y austriaco que le sirvieron de antecedentes: la "coligación" para fijar el precio del trabajo (artículo 275 del Proyecto); y la alteración por medios fraudulentos del precio de las mercaderías (artículo 276 del Proyecto).

Sin embargo, durante la "revisación" del proyecto de Código, en la sesión 156 de 17 de junio de 1873, “el señor Gandarillas manifestó que no creía justa la subsistencia del artículo 276 [275] del proyecto, porque no era posible castigar el uso lejítimo de un derecho, como es el que cada cual tiene para determinar el precio de su trabajo", entendiéndose como tal "uso legítimo" la "coligación" o acuerdo para fijarlo, pues por "coligados" que estén los oferentes o los demandantes, "en esta materia no debe admitirse otro regulador o correctivo que la misma libertad de industria, de la cual solamente puede resultar una fijación equitativa de los valores", en el juego del libre consentimiento entre demandantes y oferentes. Por estas consideraciones, estimó la Comisión Redactora que "lo único que merece castigo es el empleo de medios fraudulentos para abaratar o encarecer el precio del trabajo", y se suprimió el proyectado artículo 276 [275] y en el siguiente [antes aprobado como 276] se incorporó el trabajo entre los objetos cuyo precio podría alterarse fraudulentamente, alterándose nuevamente la pena. ${ }^{12}$

Según Fuenzalida, de esta modificación "se sigue [...] que en Chile no se penan las simples coligaciones" de empleadores y trabajadores: "unos i otros usan de su libertad, según las

\footnotetext{
${ }^{11}$ PACHECO, cit. nota ${ }^{\circ} 4$, Código penal, p. 389.

${ }^{12}$ Actas, cit. nota $\mathrm{n}^{\circ} 8$, p. 280.
} 
palabras del acta citada, i mientras no ofendan derechos ajenos garantidos por una sanción penal no deben ser castigados". ${ }^{13}$

Así, el entonces proyectado artículo 288, recogido sin modificaciones como 285 del vigente Código penal, quedó como sigue:

“Artículo 289 [hoy, 285]. Los que por medios fraudulentos consiguieren alterar el precio natural del trabajo, de los jéneros o mercaderias, acciones, rentas públicas o privadas o de cualesquiera otras cosas que fueren objetos de contratación, sufrirán las penas de reclusión menor en sus grados mínimo a medio i multa de ciento a quinientos pesos."

Fuenzalida señala entre los medios fraudulentos a que haría referencia este artículo algunos de los ejemplos del artículo 419 Código francés que no hacen referencia a la "coligación" (excluida del tenor y sentido de nuestro artículo 285, como ya se explicó): “divulgar de intento entre el pueblo hechos falsos i calumniosos o hacer ofertas ficticias a los mismos vendedores". 14 Y Fernández, luego de transcribir las mismas palabras de Pacheco aquí antes citadas ("Una carta falsa, leida en la Bolsa, un posta simulado que se haga entrar ostensiblemente para divulgar cierta noticia, etc."), ejemplifica este último caso precisamente con el del "posta" falso que en 1814, vestido de oficial de Marina inglesa, divulgó - aparentando desembarcar desde Francia- la falsa noticia de una victoria Aliada y la muerte de Napoleón a las puertas de París, lo cual significó primero una enorme ganancia para los tenedores de títulos del Gobierno Inglés, entre los que se contaba la familia y el propio Lord Cochrane, y luego, su procesamiento y condenada por haber recibido en su casa al falso oficial de Marina, quien allí se cambió de ropa para no ser descubierto. ${ }^{15}$

No obsta a lo anterior la descuidada afirmación que, en los primeros años de vigencia del Código, hacía Robustiano Vera, al afirmar - contra el texto expreso del Código, la historia de su establecimiento y la interpretación dominante- que el artículo 285 "estima delito toda coaligación, sea de empresarios o bien de operarios para forzar en un sentido o en otro el curso libre del trabajo i su precio natural, así como el de los jéneros o mercaderías, acciones, rentas públicas o privadas." En efecto, al tratar de dar sentido a estas palabras, afirma Vera en el párrafo siguiente que "lo difícil está aquí en averiguar cuándo hai delito, cómo constatarlo i de qué modo se logra el establecer los medios fraudulentos que exije la lei para estos casos" (el resaltado es nuestro). Y a continuación y sin más, reconoce Vera la necesidad de que no basta la "coligación" para constituir el delito, sino que se hace necesario para ello, además, "establecer los medios fraudulentos que exije la lei”. Y todavía más, al tratar de ejemplificar, señala que no es la huelga para solicitar un aumento de salarios (típico caso de la llamada "coligación de trabajadores") uno de los casos penados por la ley, sino que le "parece" que lo sería el de "las operaciones de bolsa que hacen los ajiotistas para hacer subir o bajar las acciones", aunque se plantea la duda de "¿cómo

\footnotetext{
${ }^{13}$ FUENZALIDA, cit. nota $\mathrm{n}^{\circ} 3$, Concordancias, p. 301.

${ }^{14}$ FUENZALIDA, cit. nota $\mathrm{n}^{\circ} 3$, Concordancias, p. 301.

${ }^{15}$ FERNÁNDEZ, cit. nota $n^{\circ}$ 9, Código, p. 34 y ss. Según este autor, el suceso habría servido para que Cochrane se decidiese a participar en nuestra Guerra de Independencia, y con el tiempo, se habría también demostrado su inocencia, pues habría sido, al parecer, utilizado por el "posta" y sus compinches, aprovechándose de una deuda de Cochrane con éste.
} 
MATUS, Jean Pierre. “Acerca de la actual falta de punibilidad en Chile de los acuerdos de precios".

perseguir y hacer constar el fraude con que se procede?”, reconociendo así una vez más la necesidad de exigir una conducta fraudulenta para que este delito se constituya, no bastando sólo el acuerdo de precios de alguna de las partes. ${ }^{16}$

Pero la Comisión no sólo dejo de sancionar la coligación de trabajadores o empleadores para la fijación de los precios del trabajo, sino que, además, adoptó otra decisión que, en conformidad al planteamiento de Gandarillas, y como consecuencia de la supresión del entonces proyectado artículo 276 [aprobado como 275 en las primeras sesiones], excluía completamente la posibilidad de considerar como delito la "coligación" o acuerdo de empleadores, vendedores, trabajadores o compradores para fijar los precios. En efecto, señala el Acta respectiva, que "a consecuencia de esta alteración se suprimió también el segundo inciso del artículo 289 (278 del proyecto anterior [aprobado como 277, según la transcripción hecha más arriba])."17

En consecuencia, se suprimió la frase que preveía, para la imposición de las penas agravadas de esta disposición, que "bastará que la coalición haya empezado a ejecutarse," razón por la cual el en definitiva aprobado artículo 289 del proyecto, que pasó a ser sin modificaciones el actual artículo 286 de vigente Código penal, sólo contempla un inciso que no hace más que reafirmar lo antes dicho, a saber, que en el Código penal se castigan únicamente los fraudes para hacer subir el precio de las mercaderías, sin que se consideren como tales las "coligaciones" o "acuerdos de precios" entre vendedores. Este artículo dispone:

“Artículo 286. Cuando el fraude expresado en el artículo anterior recayere sobre mantenimientos u otros objetos de primer necesidad, además de las penas que en él se señalan, se impondrá la de comiso de los géneros que fueren objeto del fraude."

Comentando esta disposición, y para evitar que los perjudicados por el fraude sufrieran también el comiso de sus bienes, Fuenzalida, recurriendo a la autoridad de Pacheco, afirma que "será menester aceptar que la comisión quiso decir que el comiso deberá aplicarse solamente cuando los dueños de los mantenimientos i demás objetos de primera necesidad sean los que, por medios fraudulentos, hagan subir el precio natural de las cosas."18 Fernández se limita, por su parte, a transcribir el comentario de Pacheco, agregando que "la C.R. no reprodujo esta explicación, pero es indudable que la tuvo a la vista". ${ }^{19}$ Y Vera, afirmando que "este artículo complementa el anterior estableciendo que si el fraude a que se refiere la disposición etc." 20 , ofrece aquí los mismos consabidos ejemplos del fraude

\footnotetext{
${ }^{16}$ VERA, Robustiano, Código penal de la República de Chile, comentado. Santiago: Imprenta de P. Cadot i Cía., 1883, 840 pp., p. 483. Posteriormente, Florencio BAÑADOS es el único comentarista que incurre en el mismo error de VERA, esto es, leer algún comentario francés o español y hacer de su transcripción un cometario del Código chileno, sin atender a la historia de la legislación ni a su texto, al ejemplificar como un caso punible de trust el de un comerciante ¡francés! linchado por hacer subir el precio del azúcar (BAÑADOS, Florencio, Código penal de la República de Chile concordado y comentado, Santiago: L. A. Lagunas, 1920, p. 238).

${ }^{17}$ Actas, cit. nota ${ }^{\circ} 8$, p. 280.

${ }^{18}$ FUENZALIDA, Concordancias, cit. nota $\mathrm{n}^{\circ}$ 3, p. 303.

${ }^{19}$ FERNÁNDEZ, Código, cit. nota n ${ }^{\circ}$, p. 37.

${ }^{20}$ FUENZALIDA, Concordancias, cit. nota $n^{\circ} 3$, p. 303.
} 
para subir precios en que se estaba pensando: "por avisos falsos, por un parte simulado o enviado por otro que esté de acuerdo para remitir datos falsos i de este modo elevar el precio de los efectos en cuestión". ${ }^{21}$

De este modo, se excluyó de la legislación chilena el castigo penal del acuerdo o "coligación" para la fijación del precio tanto de las mercaderías como del trabajo, quedando reducida la punibilidad de los tres casos comprendidos en los códigos austriaco y francés a la de uno solo: el de la alteración por medios fraudulentos de los precios de cualquier mercadería, incluido el trabajo.

Como señala Novoa, la reducción del ámbito de lo punible así operada es apropiada a la mentalidad de los redactores del Código y su época, pues "es perfectamente explicable que quienes partían de una supuesta igualdad entre las partes contratantes en cualquier tipo de negocio, consideraran ilícito solamente el valerse de maquinaciones dolosas (fraudes) para inducir a error a otro contratante y hacerlo caer así en un vicio del consentimiento", pero el que actuaba "sin fraude y sin error", "no podía quedar sujeto a sanción", y por lo tanto, "el artículo 285 ya citado pena únicamente a los que alteran los precios naturales (...) valiéndose de medios fraudulentos". ${ }^{22}$

\subsection{El delito del artículo 285 del Código penal en la doctrina posterior: la necesidad de un medio fraudulento para su configuración y la exclusión del acuerdo de precios como tal.}

En conformidad con lo antes expuesto, la doctrina posterior más autorizada no duda en afirmar la necesidad de la existencia de un medio fraudulento como requisito básico para la configuración de este delito, sin que ningún autor mencione como tales el acuerdo o "coligación" de oferentes o demandantes como tal, pues, en palabras de Etcheberry, "como puede advertirse de su tenor y de los antecedentes históricos (...), nuestro legislador tenía el convencimiento de que de la "libre concurrencia" no podía sino resultar siempre el precio "equitativo" o "natural" de las cosas, incluido el trabajo entre estas últimas". ${ }^{23}$

Así lo afirma Del Río, para quien este delito puede cometerse por "todos los medios conducentes a las resultantes previstas en la ley", siempre que sean "medios fraudulentos", $\mathrm{y}$ "por fraudulento debe entenderse todo procedimiento engañoso o falaz", como "las maquinaciones capaces de turbar las condiciones normales de un mercado, impidiendo la regulación automática de los valores por la ley de la oferta y la demanda y obteniendo una regulación ficticia por medio de ofertas y demandas irreales". ${ }^{24}$ Labatut, por su parte, a pesar de otorgarle a esta figura, "basada en la libertad de contratación", la amplia "finalidad de asegurar el libre juego de la oferta y la demanda, e impedir las alzas o bajas injustificadas del precio de la mano de obra y de las cosas comerciales", reduce su tipicidad a la que en él se prevé, esto es, su comisión por medios fraudulentos, que "pueden consistir en la difusión de rumores o noticias falsos, en el acaparamiento anormal de determinadas

\footnotetext{
${ }^{21}$ VERA, Código, cit. nota ${ }^{\circ} 16$, p. 484.

${ }^{22}$ NOVOA, "La legislación", cit. nota ${ }^{\circ} 2$, p. 155.

${ }^{23}$ ETCHEBERRY, Alfredo, Derecho penal, parte especial, $t$. IV. Tercera edición revisada y actualizada. Santiago: Ed. Jurídica de Chile, 1998, 382 pp., p. 280.

${ }^{24}$ DEL RÍO, J. Raimundo, Derecho penal. Tercer tomo. Santiago: Nascimento, 1935, 580 pp., p. 242.
} 
MATUS, Jean Pierre. “Acerca de la actual falta de punibilidad en Chile de los acuerdos de precios".

mercaderías, etc." 25 Finalmente, para el mencionado Etcheberry, "la expresión "medios fraudulentos" comprende cualesquiera artificios engañosos, según el concepto que ya se ha dado de ellos al tratar el de los fraudes por engaño, entre los cuales estará esparcir falsos rumores, pese a que no se nombran de modo expreso"; por lo que termina por considerar esta conducta como "semejante" al "agio: hacer variar los precios del mercado de manera artificial y con engaño para lucrar de ello". ${ }^{26}$

\section{2. ¿Constituye un acuerdo de precios entre oferentes una estafa residual y genérica del artículo 473 del Código penal?}

Según acabamos de ver, la configuración del delito del artículo 285 del Código penal requiere el despliegue de algún mecanismo o medio fraudulento que produzca la alteración de los precios naturales del mercado, esto es, de los que resultarían de la libre concurrencia entre oferentes y demandantes. Por su parte, el Profesor Etcheberry destaca que tales medios fraudulentos no son diferentes de los que se emplearían en un fraude por engaño común, cuya figura residual y genérica se encontraría regulada, entre nosotros, por el artículo 473 del Código penal.

Como hemos escrito anteriormente:

"El artículo 473 CÓDIGO PENAL castiga con la pena de presidio o relegación menores en sus grados mínimos y multa, al que "defraudare o perjudicare a otro usando de cualquier engaño que no se halle expresado en los artículos anteriores". La simpleza de este artículo se debe, básicamente, a lo expuesto por FUENZALIDA, cuyo comentario ilustra muy bien lo que con él se pretende: "El Código ha tomado en cuenta especial cuantos casos de estafas i engaños ha podido prever, auxiliado en esta materia por la lejislación antigua española, por los códigos especiales i por otras lejislaciones; pero, como esta materia es tan inconmensurable como la intelijencia y la perversidad humanas, no ha podido decir su última palabra sobre ella sino en una disposición jeneral que previniese todos los hechos olvidados i mal expresados" (el resaltado es nuestro).

Aquí, siguiendo el estilo de nuestra codificación, y tal como sucede respecto a los homicidios y las lesiones, el legislador expresó primero todos los hechos que le parecían especialmente graves, para sólo al final establecer la regla general, la figura delictiva que reúne los elementos esenciales de toda estafa, elementos a los que los casos especiales de estafa del CÓDIGO PENAL agregan las particularidades que lo identifican: el objeto material, en los fraudes en la entrega; la clase de engaño, en las estafas calificadas del artículo 468; el medio engañoso, en la falsificación de instrumentos privados; etc.

En la legislación extranjera moderna, el estilo es diferente. Desde luego, la figura básica se inserta al principio del apartado correspondiente y tiende a expresar un concepto más acabado del delito que se trata. Así, el artículo 248 CÓDIGO PENAL español de 1995, establece que "cometen estafas los que con ánimo de lucro utilizaren

\footnotetext{
${ }^{25}$ LABATUT, Gustavo, Derecho penal, Tomo II, parte especial. Séptima edición. Actualizado por el profesor Julio Zenteno Vargas. Santiago: Editorial Jurídica de Chile, 1996, 263 pp., p. 107.

${ }^{26}$ ETCHEBERRY, Derecho penal, cit. nota ${ }^{\circ} 23$, p. 280.
} 
Polít. crim. Vol. 7, No 14 (Diciembre 2012), Art. 3, pp. 318 - 356.

[http://www.politicacriminal.cl/Vol_07/n_14/Vol7N14A3.pdf]

engaño bastante para producir error en otro, induciéndolo a realizar un acto de disposición en perjuicio propio o ajeno". La novedad de este artículo es que asimila a las estafas, en su inciso segundo, el llamado fraude informático, lo que aquí no nos interesa, por el momento. Por su parte, el $\$ 263$ StGB castiga "al que con la intención de obtener para sí o para un tercero una ventaja patrimonial indebida, disminuya el patrimonio de otro, mediante la simulación, alteración u ocultación de un hecho verdadero que mantenga o provoque un error en otro"; y el el CÓDIGO PENAL italiano, en su artículo 640 sanciona penalmente "al que, con artificios o embustes, induciendo a error a otro, procura para sí o para otro un provecho injusto que importa un daño a otro".

Sin embargo, las expresiones de nuestro artículo 473 CÓDIGO PENAL comprenden sin duda la mayor parte de los elementos que se incorporan a las definiciones de las legislaciones extranjeras. En efecto, en dicha disposición se contemplan dos extremos: el engaño y el perjuicio.

El engaño consiste tanto en una actividad del agente, la simulación, alteración u ocultación de un hecho verdadero en términos del StGB, como en un efecto sobre la víctima, el error o falsa representación de la realidad.

Así lo señala expresamente el Diccionario, que define el engaño como "acción y efecto de engañar", y por engañar se entiende, en primer lugar dar a la mentira apariencia de verdad, y en segundo término, inducir a otro a tener por cierto lo que no lo es, valiéndose de palabras o de obras aparentes o fingidas.

Por otra parte, según el Diccionario el perjuicio tiene un significado asociado al Derecho más o menos preciso: "ganancia lícita que deja de obtenerse, o deméritos o gastos que se ocasionan por acto u omisión de otro, y que éste debe indemnizar, a más del daño o detrimento material causado por modo directo". O, en otras palabras, el perjuicio importa por tanto la representación de un hecho que realiza o afecta al perjudicado -una disposición patrimonial (entregar algo, perder algo, o dejar de ganar algo) - que es provocada por otro, y que tiene como resultado una pérdida patrimonial avaluable en dinero - el perjuicio-.

Por tanto, los elementos objetivos específicos de esta figura legal son:

i) El engaño (acción de engañar);

ii) El error que ese engaño produce en la víctima (efecto de engañar);

iii) La disposición patrimonial (acto que genera el perjuicio) que provoca el autor del delito mediante su engaño; y

iv) El perjuicio patrimonial (pérdida propiamente tal) que sufre una persona.

Además, así como entre la acción de matar y la muerte del ofendido en el homicidio, entre el engaño y el resultado del delito (el perjuicio patrimonial), debe existir una relación causal; esto es, debe poder imputarse objetivamente al autor del engaño el resultado que se trata de evitar (el perjuicio). Sin embargo, a diferencia de un delito simple de resultado, como el homicidio, aquí la cadena causal es mucho más extensa, y abarca los siguientes extremos: i) el engaño debe producir el error; ii) el error, la disposición patrimonial; y iii) la disposición patrimonial, el perjuicio. 
MATUS, Jean Pierre. “Acerca de la actual falta de punibilidad en Chile de los acuerdos de precios".

De allí que es más o menos comprensible que a partir de la obra de ANTÓN sobre la estafa, la doctrina y jurisprudencia españolas vinieran afirmando un concepto de la misma que incluía todos los elementos recogidos posteriormente en la reforma de 1983 y en el actual CÓDIGO PENAL español de 1995: engaño, error, acto de disposición patrimonial, perjuicio, ánimo de lucro y vinculación causal y funcional entre los cuatro primeros extremos.

Con más o menos variantes, este concepto y los elementos del delito que de él emanan son admitidos por la doctrina nacional. Así, ETCHEBERRY afirma que "los elementos típicos del fraude por engaño son: La simulación, el error, la disposición patrimonial y el perjuicio", discutiendo acerca de la viabilidad de exigir en Chile un elemento subjetivo adicional, como sería el ánimo de lucro, elemento que LABATUT agrega a los ya mencionados, junto con el requisito de "idoneidad para estafar" que debiera cumplir el engaño, el que se estudiará a propósito del concepto de engaño propiamente tal. A este respecto, nosotros estimamos más acertada la aproximación de ETCHEBERRY, pues no parece existir en las disposiciones relativas a las estafas ningún elemento que haga deducir la existencia de un ánimo especial, como sí lo requieren expresamente las legislaciones extranjeras antes citadas. Sin embargo, alguna jurisprudencia parece considerar la necesidad de exigir este ánimo adicional.,"27

Sobre la base de estos principios cabe preguntarse, luego, si los hechos constitutivos de un acuerdo de precios entre oferentes, podrían eventualmente constituir un engaño, comprendido y castigado genéricamente en el artículo 473 del Código penal.

\subsection{El acuerdo de precios entre oferentes no constituye engaño del artículo 473 del Código penal.}

2.1.1. El argumento histórico: imposibilidad de considerar simultáneamente punible el acuerdo de precios bajo el mismo texto legal en cuya redacción se consideró expresamente lícito al discutirse la del artículo 285 del Código penal.

Como acabamos de demostrar en el análisis del artículo 285 del Código penal, el acuerdo de precios entre oferentes no fue considerado por el legislador histórico un engaño asimilable a los medios fraudulentos que, como la carta falsa leída en la bolsa, el posta de correos que difunde una noticia falsa u otros semejantes, produciría que tanto oferentes como demandantes atribuyesen al trabajo o a las mercaderías un valor diferente del que naturalmente les atribuirían sin esa falsa información. Al contrario, allí se afirmó que estos acuerdos suponían una forma de ejercicio legítimo del derecho a participar en las actividades económicas, mientras no se engañara o coaccionara a terceros de alguna otra manera, para alterar con ello los precios naturales que surgirían de la libre concurrencia en el mercado de oferentes y demandantes.

Luego, cabe afirmar, que dado que el texto del artículo 285 del Código penal fue promulgado simultáneamente con el del artículo 473, se puede concluir que no es posible suponer que el legislador haya considerado simultáneamente como punible, bajo el título

${ }^{27}$ POLITOFF, Sergio; MATUS, Jean Pierre; RAMÍREZ, M Cecilia. Lecciones de Derecho penal chileno, parte especial, $2^{a}$ edición. Santiago: Ed. Jurídica de Chile, 2005, 685 pp., pp. 416-419. Allí se encuentran las referencias bibliográficas a los autores y textos citados. 
genérico de estafa, un hecho -el acuerdo de precios entre oferentes- que expresamente consideró lícito al momento de discutirse en detalle el texto que se refiere específicamente a las alteraciones fraudulentas de precios.

2.1.2. El argumento de fondo: no hay engaño en la oferta de un bien mueble determinado a un precio fijado por el vendedor y conocido de antemano por el comprador.

Hemos señalado que, para que exista estafa residual o genérica, es necesaria la existencia de un engaño, esto es, de la defraudación a que hace referencia el artículo 473 del Código penal. Luego, si suponemos que nuestros legisladores de 1874 no hubiesen declarado expresamente como lícitos los acuerdos de precios para excluir su punibilidad del artículo 285 del Código penal, podríamos preguntarnos si tales hechos, podrían constituir un engaño en los términos del mencionado artículo 473.

\title{
Al respecto, hemos señalado anteriormente que
}

\begin{abstract}
"Según Etcheberry, el engaño, que él denomina "simulación", es, en sentido amplio "cualquier acción u omisión que pueda crear en otro una falsa representación de la realidad", y según Labatut, "el engaño consiste en la mutación o alteración de la verdad, tendiente a provocar o mantener el error ajeno, como medio de conseguir la entrega de la cosa". En la doctrina española, Bustos se refiere al "ardid, una determinada maquinación o simulación por parte del sujeto, (...) que tiene la aptitud suficiente para inducir a error a otro" y más sencillamente Bajo/Pérez, hablan de una "falta a la verdad en lo que se dice o hace de modo bastante para producir error e inducir al acto de disposición patrimonial". Es interesante anotar que estos últimos autores parecen considerar la expresión "cualquier engaño" antes vigente en España, como indicativa de engaños que podrían ser simples mentiras. Por su parte, Cramer/Schönke/Schröder sostienen que engaño es "cualquier conducta que, influyendo en la representación intelectual de otro, le conduzca a una falsa idea de la realidad o lo mantenga en ella".,28
\end{abstract}

Luego, en cuanto al precio de las cosas, habrá que concluirse que una imputación de estafa en este materia se refiere al hecho de inducir a un tercero a la adquisición de un bien a un precio diferente al que se le señaló en la oferta de venta, como si se le dijese que un bien cuesta una cantidad determinada según una fórmula que se le señala $y$, en definitiva, se le cobrase otra diferente bajo cualquier pretexto falso. El comprador habría recibido una información que le conduciría a tener una falsa o errónea representación de la realidad sobre el verdadero precio que el oferente había fijado a la cosa.

Pero en los casos en que los precios están publicados de antemano, se pueden consultar por diferentes vías y se puede rechazar la oferta al conocerse su cantidad exacta, como sucede típicamente en las ventas minoristas de la actualidad $\mathrm{y}$, en particular, en los establecimientos farmacéuticos modernos, el comprador siempre tiene una representación de la realidad que se ajusta a la verdad: el precio de venta ofrecido es el precio de venta que se va a cobrar al momento del pago.

\footnotetext{
${ }^{28}$ POLITOFF/MATUS/RAMÍREZ, Lecciones de Derecho penal chileno, cit. nota ${ }^{\circ} 27$, pp. 423 y ss., donde se encuentran las correspondientes referencias bibliográficas.
} 
MATUS, Jean Pierre. “Acerca de la actual falta de punibilidad en Chile de los acuerdos de precios".

Luego, falta en esta clase de operaciones el engaño típico de la estafa residual o genérica del artículo 473.

No influye en esta conclusión el hecho de que el o los compradores tuviesen determinada de antemano la compra, por las razones que sean, o que éstos esperasen un precio de oferta menor al efectivamente ofrecido. En ambos casos, se trata de situaciones en que, cualquiera sea la conducta del oferente, ésta no influye en la decisión del demandante y, por tanto, no existe engaño ni estafa alguna, por faltar la relación causal entre la conducta del oferente y la disposición patrimonial (la decisión de compra del demandante). En el primero, porque se trata de una decisión preexistente, y en el segundo, porque se le informa previa y adecuadamente que el verdadero precio de la oferta no es el que él espera, sino otro diferente $\mathrm{y}$, por lo tanto, no hay engaño alguno en cobrarle el precio informado previamente.

Nótese que, respecto del consumidor o comprador, la situación es idéntica tanto en casos de acuerdos de precios que él estime mayores a los que espera, como en la situación inversa, esto es, cuando los acuerdos de precios producen el efecto de dumping o precios depredatorios: el consumidor conoce el precio de venta y, aunque le resulte curioso que sea menor al que él esperaba o a los anteriores preexistentes, acepta la oferta libremente, pues adquiere el producto al precio ofertado y es ése precio el que se cobra efectivamente sin coacción ni engaño.

De lo anterior se deduce que ninguna influencia tiene para el precio que se informa al consumidor que éste haya sido acordado de manera "abierta" o "secreta" (distinción por lo demás inexistente en las leyes que castigan los acuerdos de precios), como parecen dar a entender quienes destacan la expresión "colusión" (concepto periodístico sin respaldo legal en el Artículo 285) como un caso especial de "acuerdo secreto" que identifican, sin fundamento legal alguno, como un "fraude al consumidor". En efecto, es más o menos obvio que un "acuerdo de precios abierto" es una quimera sin ningún respaldo en la realidad, pues los que se persiguen son los "secretos", como es más o menso obvio, pues nadie hace un "acuerdo abierto" para exponerse a las sanciones, ahora administrativas, por acordar precios! Además, tanto si el acuerdo es "abierto" o "secreto", ello no afecta al hecho de que el consumidor conoce de antemano el precio de lo que adquiere y no se emplea ninguna fórmula que, al momento del pago, lo altere. Y ello tanto si el precio aparece como excesivo (lo cual no obliga a comprar existiendo otros proveedores no "coludidos"), como cuando aparece como "beneficioso" para el consumidor, por provenir de una práctica depredatoria. Estos acuerdos no afectan la inteligencia del consumidor al momento de adquirir los bienes que se tratan, sino la libre competencia, esto es, un bien jurídico supraindividual (lo que queda muy claro cuando se trata de precios "depredatorios" que, aparentemente, "benefician" a consumidores finales concretos).

${ }^{29}$ Así, HERNÁNDEZ, Héctor, "La punibilidad de la colusión (secreta) de precios en el derecho chileno", Polit. crim., Vol. 7, $\mathrm{N}^{\mathrm{o}} 13$ (Julio 2012), Artículo 4, pp. 147 - 167, en http://www.politicacriminal.cl/Vol_07/n_13/Vol7N13A4.pdf 
De hecho, esto explica el que, en su extenso requerimiento de 9 de diciembre de 2008, el Sr. Fiscal Nacional Económico no mencionase ni imputase en ninguna de sus 41 fojas la realización por parte de las imputadas o sus representantes, de ninguna actividad o conducta que califique de "engaño" a algún consumidor particular. Es más, la palabra "engaño" no es usada ni una sola vez en el mencionado requerimiento. Y la expresión "fraude" se usa solo una vez, en su apartado 34, al señalarse que "la colusión de precios" es "un verdadero fraude a la libre competencia" (y así lo califica la letra a) del artículo $3^{\circ}$ del texto refundido del Decreto Ley $\mathrm{N}^{\mathrm{o}} 211$ ), pero no a consumidores particulares.

Es por estas razones históricas y dogmáticas que, con el desarrollo de nuestra sociedad, se hizo necesaria una regulación nueva y singular que diera cabal cuenta de que, desde el punto de vista del normal funcionamiento de la economía moderna, y a pesar de que no exista engaño o maquinación fraudulenta alguna respecto de particulares, pueda considerarse como una infracción o fraude a la libre competencia como tal el acuerdo de precios entre oferentes o demandantes, tanto si, según su contenido y prima facie, puede considerarse perjudicial o favorable (como en los acuerdos de precios depredatorios) a los intereses de los consumidores o proveedores particulares. Esta regulación nueva y singular de la libre competencia es la que, entre nosotros, tiene su primera manifestación el año 1959, con la promulgación de la Ley $\mathrm{N}^{\mathrm{0}} 13.305$, de 1959, que es reemplazada en 1973 por el Decreto Ley No 211, y ha sido recientemente perfeccionada por las Leyes $\mathrm{N}^{\mathrm{o}} \mathrm{s} 19.911 \mathrm{y}$ 20.361, cuyos alcances y efectos expondremos a continuación.

\section{La regulación en la legislación especial: desde la tipificación operada en la Ley $\mathbf{N}^{\mathbf{0}}$ 13.305 hasta la despenalización contemplada en la Ley $\mathbf{N}^{\circ} 19.911$, de 13 de julio de 2009.}

\subsection{Generalidades: la regulación de la libre competencia como derecho nuevo y singular.}

En general, parece acertado afirmar que la protección y regulación de la libre concurrencia por parte del Estado significa dejar de lado el supuesto según el cual, en todos los casos, los precios de las mercaderías serían determinados por una real "libre concurrencia" de oferentes y demandantes, libertad de contratación que, particularmente, se dificultaría en situaciones que pueden calificarse como "monopólicas", donde los grados de libertad de una de las partes concurrentes pueden (aunque no necesariamente) llegar a ser muy superiores a los de la otra, según las condiciones de cada mercado en particular.

Por lo tanto, una regulación de esta naturaleza, que se vea reforzada con medidas de carácter penal, constituye, frente a los principios generales que gobernaron la regulación penal económica del Código de 1874, un derecho nuevo y singular. ${ }^{30}$ Derecho nuevo no sólo por su lejanía temporal (la Ley N $\mathrm{N}^{\circ}$ 13.305, de 6 de abril de 1959 se dictó 85 años después de la entrada en vigencia del Código), sino por la materia a tratar: las actividades contra la libre competencia, no reguladas por el Código de 1874. Y singular, pues no sólo presupone la incapacidad del libre consentimiento para validar todos los actos contra la

\footnotetext{
${ }^{30}$ Las categorías están tomadas del texto de GUZMÁN BRITO, Alejandro, "Codificación, descodificación y recodificación del Derecho civil en Chile”, Revista de Derecho y Jurisprudencia, TOMO XC, No 2 (1993), pp. 39-62 [tomada de MICROJURIS: MJCH_MJD117| RDJ 90-2-39].
} 
MATUS, Jean Pierre. “Acerca de la actual falta de punibilidad en Chile de los acuerdos de precios".

libre competencia, sino también una tipificación especial, requisitos de procesabilidad extraordinarios, intervención de órganos administrativos en su persecución, y un procedimiento más o menos extraordinario.

\subsection{Penalización de la celebración de acuerdos de precios tendientes a impedir la libre competencia: La Ley $\mathrm{N}^{\circ}$ 13.305.}

En cuanto a la tipificación especial, en nuestro sistema jurídico, las conductas contra la libre competencia se tipificaron como tales, por primera vez, en el Título V de la Ley $\mathrm{N}^{\circ}$ 13.035 de 6 de abril de 1959, que establecía "normas para fomentar la libre competencia industrial y comercial", y cuyo artículo 173 castigaba, con la pena de presidio menor en cualquiera de sus grados y multa,

"todo acto o convención que tienda a impedir la libre competencia dentro del país, sea mediante convenios de fijación de precios o repartos de cuotas de producción, transporte o de distribución de zonas de mercado; sea mediante acuerdos, negociaciones o asociaciones para obtener reducciones o paralizaciones de producción; sea mediante la distribución exclusiva, hecha a una sola persona o sociedad, de varios productores del mismo artículo específico, o por medio de cualquier otro arbitrio que tenga por finalidad eliminar la libre competencia."

Esta disposición, en lo que aquí interesa, esto es, en cuanto califica como delito "todo acto o convención que tienda a impedir la libre competencia dentro del país ... mediante convenios de fijación de precios", fue, a la fecha de su ingreso a nuestro sistema jurídico, completamente novedosa y singular. Novedosa, por cuanto los convenios de precios no eran delito en conformidad con los artículos 285 y 473 del Código penal, si no había de por medio una maquinación dolosa (fraude) que hiciere recaer en otro engaño o error; y singular, pues se refería a una materia hasta el momento no regulada y respecto de la cual el consentimiento, aún de los afectados, no jugaba un rol, pasando desde ese momento a considerarse como un ejercicio ilegítimo del derecho de libre contratación, hacerlo para "impedir la libre competencia". A partir de ese momento, sólo el consentimiento del Estado, expresado en una autorización del Presidente de la República, pasó a considerarse como válido para legitimar tales actos, cuando en ellos participaran empresas del Estado y, en general, "siempre que el interés nacional" así lo exigiese (artículo 174).

Otra singularidad en la tipificación, consistió en el establecimiento de responsabilidad penal para las personas jurídicas, al respecto de las cuales disponía el inciso final del artículo 173:

"En el caso de personas jurídicas, si se tratare de reincidencia, además de la multa señalada en el inciso primero y de la responsabilidad penal que sea imputable a sus representantes, podrá el Tribunal aplicar, como pena accesoria la cancelación de la personalidad jurídica, la revocación de la autorización de existencia si se tratare de una sociedad anónima o de una agencia de sociedad anónima extranjera, o la disolución anticipada en los demás casos. La sentencia que aplique estas penas, tratándose de una sociedad anónima o comercial o de una agencia de sociedad anónima extranjera deberá ser inscrita en el Registro de Comercio respectivo y publicada en el "Diario Oficial"." 
Al mismo tiempo, se estableció un órgano especial, "la Comisión", compuesta por un Ministro de la Corte Suprema y los Superintendentes de Bancos y Compañías de Seguros, Sociedades Anónimas y Bolsas de Comercio (artículo 175), encargado de "conocer, ya sea de oficio o a petición de cualquiera persona natural o jurídica, de las situaciones que puedan estar comprendidas en el artículo 173, a fin de declarar si procede o no la iniciación del proceso respectivo ante los Tribunales de Justicia” (artículo 175, letra a)).

A ello se añadió un requisito especial de procesabilidad: el inicio del proceso penal por medio de querella o denuncia por parte del Consejo de Defensa del Estado, "a requerimiento de la Comisión" (artículo 177), amén de algunas importantes modificaciones procesales, particularmente en lo relativo a la apreciación de la prueba (en conciencia), el Tribunal competente (un Ministro de Corte de Apelaciones), y las facultades de investigación conferidas a la Comisión y al Consejo de Defensa del Estado (artículos 178 a 180).

Es más, un estudio detallado de la historia del establecimiento de la Ley $\mathrm{N}^{\mathrm{o}} 13.305$, en cuyo artículo 173 se sanciona por primera vez las convenciones o acuerdos para fijar precios, demuestra que en su concepción y primeras interpretaciones, se entendía que con ella venía a llenar un vacío necesitado de regulación, pues las conductas monopólicas como la señalada no estarían sancionadas en el Código penal o en otras disposiciones especiales. Así en el Mensaje presidencial respectivo, sólo se señala que se pretende alcanzar el objetivo de aumentar la competencia y disminuir con ella los precios, "calificando de delito todo tipo de convenio o asociación que tienda a impedir la libre competencia", sin hacer siquiera mención a su potencial regulación anterior por el Código penal o a eventuales problemas prácticos para aplicar a tales hechos su artículo 285. Es más, este artículo no se menciona en ninguno de los ocho tomos de discusión legislativa. ${ }^{31}$

Por su parte al inaugurar las Quintas Jornadas de Ciencias Penales, el su discurso inaugural, el Sr. Ministro de Justicia de ese entonces, don Enrique Ortúzar, señalaba: que "el actual Gobierno, en el convencimiento de la necesidad de proteger el orden público económico, patrocinó y obtuvo la dictación de una ley que reprime los monopolios, delito inequívocamente de naturaleza económica". Y a ello agregaba: "En efecto, en el Título V de la Ley $\mathrm{N}^{\mathrm{o}} 13.305$ se sanciona todo acto o convención que tienda a impedir la libre competencia". 32

Y el entonces Ministro de la Excma. Corte Suprema, don Eduardo Varas, explicaba que el Código penal se dictó bajo la premisa de que "los hombres actuaban libres" y que "el bien jurídico era el patrimonio de la víctima, amagado por medio de la estafa, de la usura y de la defraudación", castigando el artículo 285 del Código penal, sólo a los que "por medios fraudulentos" conseguían alterar los precios. Pero, agregaba, "faltaba aún en Chile la represión de los monopolios y fue el actual Gobierno, en enero de 1959, el que deseoso de

\footnotetext{
${ }^{31}$ Biblioteca del Congreso Nacional, Historia de la Ley $N^{o}$ 13.305. El Mensaje se encuentra en los Documentos de la Cuenta de la Sesión No 24, de 13.01.1959 de la Cámara de Diputados, y lo citado, en su p. 1316.

${ }^{32}$ ORTÚZAR, Enrique, "Discurso del acto inaugural de las Quintas Jornadas de Ciencias Penales", Revista de Ciencias Penales, T. XXI (1962), pp. 6-10, p. 9.
} 
MATUS, Jean Pierre. “Acerca de la actual falta de punibilidad en Chile de los acuerdos de precios".

combatir las alzas injustificadas de precios y permitir en su integridad la libre competencia presentó al Parlamento el Proyecto de la Ley $\mathrm{N}^{\circ}$ 13.305", donde se proponía "sancionar como delitos los acuerdos, pactos o convenciones que los particulares pudieran concertar, con el objeto de impedir la libre competencia", entre los cuales se encuentran precisamente los "convenios de fijación de precios", según quedó establecido en el artículo 173 de dicho cuerpo legal. ${ }^{33}$

En el mismo sentido, Luis Cousiño M. afirmaba que "basta un análisis superficial" de los delitos contemplados en el párrafo $7^{\circ}$ del Título VI del Libro II del Código penal (entre ellos, el del artículo 285), "para advertir que su objeto jurídico está radicado en los intereses particulares -no públicos- del industrial, del contratante o del dueño de la empresa subastada, sin que los prive de esta calidad la circunstancia de que en el artículo 286 se contenga una pena accesoria si la alteración del precio natural "recayere en mantenimientos u otros objetos de primera necesidad", porque el eje sobre el cual giran los varios preceptos es el fraude, esto es, el perjuicio sufrido mediante engaño, abuso de confianza o incumplimiento doloso y no la naturaleza socioeconómica de dichos objetos de primera necesidad". Y aunque no considera la figura del artículo 173 de la Ley $\mathrm{N}^{\mathrm{o}} 13.305$ como una que proteja los intereses socioeconómicos del Estado, sino "la libertad de acceso a la industria y al comercio", tampoco entiende que ella sea superflua o esté comprendida en el delito del artículo 285, destinado a la protección del patrimonio individual contra el fraude, sino que, al contrario, propone lo que entiende una mejor regulación del monopolio, entre cuyos casos considera explícitamente deberían sancionarse los "convenio de fijación de precios". 34

Finalmente, para disipar toda duda de regulación, se estableció una regla derogatoria general en su artículo 181, que, mediante la técnica de dejar subsistentes las disposiciones que expresamente indica, deroga todas las restantes que directa o indirectamente regulasen la materia, cuyos efectos analizaremos a continuación

\subsubsection{Efectos derogatorios de la Ley $\mathrm{N}^{\mathrm{o}} 13.305$ y del Decreto Ley $\mathrm{N}^{\mathrm{o}} 211$ de 1974.}

Luego, si a pesar de los argumentos antes señalados, se insistiese en afirmar que el artículo 285 del Código penal pudiera ser interpretado para dar cabida en el mismo a la sanción penal de los meros acuerdos de precios entre proveedores, surge la cuestión acerca de su vigencia en la actualidad, dado el carácter nuevo e integral de la regulación antimonopolios surgida en Chile el año 1959.

Según lo ya afirmado la respuesta a tal pregunta es negativa: de haber sancionado el artículo 285 del Código penal los acuerdos de precios con anterioridad a la promulgación de la Ley $\mathrm{N}^{\mathrm{o}}$ 13.305, ésta la habría derogado en lo relativo a dichos acuerdos de precios, al establecer una regulación integral en la materia, esto es, un derecho nuevo y singular aplicable precisamente al caso que nos ocupa (los meros acuerdos de precios entre

\footnotetext{
${ }^{33}$ VARAS, Eduardo, "Discurso del acto inaugural de las Quintas Jornadas de Ciencias Penales", Revista de Ciencias Penales, T. XXI (1962), pp. 10-16, pp. 11, 13 y 14.

${ }^{34}$ COUSIÑO M., Luis, "El delito socioeconómico", Revista de Ciencias Penales, T. XXI (1962), pp. 47-63, pp. $48-50,59$ y ss.
} 
Polít. crim. Vol. 7, No 14 (Diciembre 2012), Art. 3, pp. 318 - 356.

[http://www.politicacriminal.cl/Vol_07/n_14/Vol7N14A3.pdf]

proveedores, calificándolos como una conducta monopolística), diferenciado del régimen penal ordinario sin hacer referencia al mencionado artículo 285 del Código penal en la disposición que declara la subsistencia de otras normas referidas a la materia (artículo 181), con lo cual, si éste hubiese abarcado tales hechos, se encuentra en la actualidad derogado.

Para fundamentar esta afirmación, es necesario ahora hacernos cargos de los conceptos involucrados.

- La derogación y sus efectos

i) Clases de derogación.

El Código Civil señala en sus artículos 52 y 53 lo siguiente:

"Artículo 52. La derogación de las leyes puede ser expresa o tácita.

Es expresa, cuando la ley nueva dice expresamente que deroga la antigua.

Es tácita, cuando una nueva ley contiene disposiciones que no pueden conciliarse con las de la ley anterior.

La derogación de una ley puede ser total o parcial".

“Artículo 53. La derogación tácita deja vigente en las leyes anteriores, aunque versen sobre la misma materia, todo aquello que no pugna con las disposiciones de la nueva ley"

Según la doctrina civil más autorizada, "es indudable la mayor conveniencia de usar la derogación expresa", pues con ella "se evita las dudas", facilitando la labor del juez, pero que existen "diversas razones" para no recurrir a ella: pereza legislativa, rapidez del proceso de despacho de las leyes, imposibilidad de tener presente todas las leyes aplicables en la materia. Por lo mismo, la derogación tácita opera siempre que se dicte una nueva ley, aunque ella nada diga al respecto. Es más, según la doctrina citada, la existencia de la regla de la derogación tácita en el Código Civil "pone de manifiesto la inutilidad del artículo final de muchas leyes chilenas y francesas, cuyo tenor declara abolidas "todas las leyes contrarias a la presente"", 35

ii) Un caso especial de derogación tácita: derogación por ley especial posterior incompatible.

Siguiendo la doctrina civil, allí se señala que

"es indudable que si con posterioridad a una ley general se promulga una especial, ésta prevalece sobre aquélla en todo lo que sean incompatibles; deroga las disposiciones

\footnotetext{
${ }^{35}$ ALESSANDRI R., Arturo; SOMARRIVA U., Manuel; VODANOVIC H., Antonio, Derecho Civil, T. I, Parte General y de las Personas, $2^{a}$ ed., Santiago: Ed. Nascimento, 1945, p. 218. Una disposición de esa naturaleza, que seguía a la del artículo 181 de la Ley $N^{\circ} 13.305$ en el proyecto aprobado por la Cámara de Diputados en su primer trámite constitucional, fue suprimida por el Senado, entendemos por ser, precisamente, inútil (Informe Comisiones Unidas del Senado, Diario de Sesiones del Senado, Sesión 20 a (1959) (Anexo Documentos), pp. 755-855, especialmente pp. 705p., 766 y ss., y 795. La disposición proyectada y suprimida decía: "Artículo 134. Se derogan todos aquellos preceptos legales y reglamentarios contrarios a las disposiciones de este Título".
} 
MATUS, Jean Pierre. “Acerca de la actual falta de punibilidad en Chile de los acuerdos de precios".

que no puedan coexistir con las suyas propias. Esto resulta de la mera aplicación de los principios generales de la derogación tácita". 36

iii) Otro caso especial: la derogación orgánica.

Según L. Ortega, existe "otra especie de derogación tácita: la derogación orgánica”, que ocurre cuando el legislador, "sin una necesidad de regulación expresa", "regula toda la materia ya regulada por la ley anterior", no siendo "indispensable que exista incompatibilidad entre la antigua y la nueva ley", sino más bien, que la segunda ley "se hay inspirado en principios distintos de los que lo movieron a dictar la primera". ${ }^{37}$

- Efectos de la derogación.

Cualquiera que sea la clase de derogación que se trate, sus efectos son los mismos: la expulsión del sistema de la ley o disposición derogada, sin posibilidad de volver a regir, salvo remisión expresa de una ley posterior que así lo permita:

"Es necesario, pues, que una ley expresamente devuelve su vigor a la ley derogada: la simple abolición de la ley derogatoria no puede por si sólo dar vida a lo que ya no existe. Y es lógico que así sea. La ley es la declaración positiva y actual del legislador; su existencia no puede desprenderse por meras conjeturas". 38

Y si lo dicho vale para el Derecho civil, mucho más ha de ser necesario respecto del Derecho penal, donde la garantía del principio de legalidad impone considerar no punibles aquellos hechos que no están expresamente descritos como delitos en una ley vigente al momento de su comisión (artículo $19 \mathrm{~N}^{\mathrm{o}} 3$, inciso $8^{\circ}$ de la Constitución Política de la República). Luego, parafraseando la cita anterior, podríamos decir, que un delito derogado por una ley posterior no puede "revivirse" por efecto de meras conjeturas acerca del alcance de la derogación de esa ley posterior, si tal "resurgimiento" no ha sido expresamente establecido por el legislador, como expresión de su voluntad soberana.

- ¿Derogó la Ley $\mathrm{N}^{0}$ 13.305, de 1959, el artículo 285 del Código penal en relación con los acuerdos de precios entre proveedores?

Como ya hemos señalado, esta pregunta supone conceder, de manera retórica únicamente, que el artículo 285 del Código penal, al castigar al que fraudulentamente alterare el precio natural de las cosas objeto de comercio que allí se indican, incluye no sólo el caso del agio, sino también, el del mero acuerdo de precios entre proveedores.

Aceptando esta premisa hipotética, para resolver la pregunta planteada habría que estudiar el contenido del Título V la Ley N ${ }^{0} 13.305$, de 1959, y especialmente sus artículos 173 y 181.

\footnotetext{
${ }^{36}$ ALESSANDRI/SOMARRIVA/VODANOVIC, Derecho Civil I, cit. nota ${ }^{\circ}$ 35, p. 222.

${ }^{37}$ ORTEGA, Leopoldo, "De la derogación de las leyes y especialmente de la derogación orgánica", Revista de Derecho y Jurisprudencia, T. XXXV (1938), Primera Parte, pp. 6-12, pp. 8 y ss.

${ }^{38}$ ALESSANDRI/SOMARRIVA/VODANOVIC, Derecho Civil I, cit. nota ${ }^{\circ}$ 35, p. 222.
} 
Polít. crim. Vol. 7, No 14 (Diciembre 2012), Art. 3, pp. 318 - 356.

[http://www.politicacriminal.cl/Vol_07/n_14/Vol7N14A3.pdf]

El artículo 173 mencionado establecía:

“Artículo 173. Todo acto o convención que tienda a impedir la libre competencia dentro del país, sea mediante convenios de fijación de precios o repartos de cuotas de producción, transporte o de distribución, o de zonas de mercado; sea mediante acuerdos, negociaciones o asociaciones para obtener reducciones o paralizaciones de producción; sea mediante la distribución exclusiva, hecha por una sola persona o sociedad, de varios productores del mismo artículo específico, o por medio de cualquier otro arbitrio que tenga por finalidad eliminar la libre competencia, será penado con presidio menor en cualquiera de sus grados y con multa de uno por ciento al diez por ciento del capital en giro de los autores.

Los cómplices o encubridores serán penados con la multa señalada en el inciso anterior.

En el caso de personas jurídicas, si se tratare de reincidencia, además de la multa señalada en el inciso primero y de la responsabilidad penal que sea imputable a sus representantes, podrá el Tribunal aplicar, como pena accesoria la cancelación de la personalidad jurídica, la revocación de la autorización de existencia si se tratare de una sociedad anónima o de una agencia de sociedad anónima extranjera, o la disolución anticipada en los demás casos. La sentencia que aplique estas penas, tratándose de una sociedad anónima o comercial o de una agencia de sociedad anónima extranjera deberá ser inscrita en el Registro de Comercio respectivo y publicada en el "Diario Oficial"."

De su sola lectura, se desprende que una de las situaciones consideradas como delito de monopolio o, más propiamente, contra la libre competencia industrial y comercial (objeto que el Título V de la Ley $\mathrm{N}^{\mathrm{o}} 13.305$ se proponía fomentar, mediante, entre otras medidas, esta disposición de carácter penal), era la celebración de actos consistentes en "convenios de fijación de precios".

Por lo tanto, de ser cierto que el artículo 285 del Código penal castigaba en 1874 la celebración de acuerdos o convenciones para fijar los precios como un caso especial de alteración fraudulenta de los precios naturales de las cosas, no lo es menos que casi 85 años después, de manera explícita e indubitable, el artículo 173 de la Ley $\mathrm{N}^{\mathrm{0}} 13.305$ también lo contempló como un caso especial de delito monopolístico.

Es decir, en lo que toca al acuerdo de precios, el artículo 173 de la Ley No 13.305, de 1959, es una norma posterior frente al artículo 285 del Código penal de 1874 . Y, además, es una norma especial, no sólo porque el artículo 285 incluye al menos otro caso (el agio) no contemplado en el artículo 13 de la Ley $\mathrm{N}^{\circ}$ 13.305, sino, principalmente, por la especial regulación complementaria a que se somete el delito de acuerdo de precios en el Título $\mathrm{V}$ de la Ley $\mathrm{N}^{\mathrm{o}} 13.305$.

En efecto, según se señala en la historia de su establecimiento, mientras el Proyecto contenido en el Mensaje del Ejecutivo contemplaba como única limitación para el ejercicio de la acción penal por esta clase de infracciones una denuncia o querella previa del Consejo de Defensa del Estado (régimen ya diferenciado de la acción pública que contemplaba el artículo 285 del Código penal), al estudiarse el mismo en las Comisiones Unidas de la Cámara de Diputados, y con la finalidad dar al comercio y a la industria la seguridad de 
MATUS, Jean Pierre. “Acerca de la actual falta de punibilidad en Chile de los acuerdos de precios".

que este delito no sería empleado en su contra "en forma abusiva, mediante denuncias o querellas infundadas", se acordó establecer el sistema de "calificación previa" por parte de una Comisión permanente, formada por un Ministro de la Corte Suprema y los Superintendentes de Bancos y de Sociedades Anónimas. ${ }^{39}$ Luego, sólo cuando esta Comisión estableciera la efectividad de una infracción de las normas antimonopolios, se podían enviar los antecedentes a la justicia ordinaria a través del Consejo de Defensa del Estado, restando la posibilidad de que los jueces y los particulares pudieran accionar de oficio o por medio de querellas o denuncias sobre estos hechos. ${ }^{40}$ Este sistema quedó reflejado básicamente en los artículos 175 y 177 de la Ley $\mathrm{N}^{\circ}$ 13.305. Es más, el artículo 179 del texto aprobado entregó la competencia para conocer de estos asuntos a un Ministro de la Corte de Apelaciones respectiva, privando de ella a los jueces ordinarios que sí tenían competencia para conocer de los casos por infracción al artículo 285 del Código penal.

De allí se desprende que la intención manifestada objetivamente en la ley y en la historia de su establecimiento era que las infracciones a la libre competencia consistentes en celebrar convenciones para fijar precios, se regirían por un sistema diferenciado tanto en su penalidad (que pasaba a regirse por el artículo 173 de la Ley $\mathrm{N}^{\mathrm{o}} 13.305$, como en la forma de ejercer la acción penal, dejando de ser pública propiamente tal, y en la competencia para su conocimiento, quedando entregado en primer lugar a una Comisión y, sólo en caso que ésta así lo decidiera, a un Ministro de Corte de Apelaciones.

Esta especialidad en sus presupuestos procesales hacía al artículo 173 de la Ley $\mathrm{N}^{\mathrm{o}} 13.305$, de 1959, incompatible con la eventual subsunción de los acuerdos de precios como un caso del artículo 285 del Código penal, regido por el sistema de persecución penal ordinario de la época. En efecto, de sostener lo contrario, habría que suponer que durante toda la vigencia de la Ley $\mathrm{N}^{\mathrm{o}} 13.305$ los acuerdos de precios podrían haberse perseguido penalmente por el régimen ordinario que correspondía al Código penal de 1874, lo que habría frustrado el propósito y objetivos del sistema especialmente diseñado para su investigación y sanción por la Ley $\mathrm{N}^{\mathrm{o}} 13.305$, esto es, evitar su persecución por la justicia ordinaria a través de denuncias y querellas de particulares, estableciendo un antejuicio ante la Comisión, reservando el ejercicio de la acción penal exclusivamente al Consejo de Defensa del Estado.

Luego, por tratarse el artículo 173 de la Ley $\mathrm{N}^{\circ} 13.305$ de una ley especial y posterior, incompatible con el artículo 285 del Código penal, debe entenderse que éste fue derogado por aquella si éste también sancionara los acuerdos de precios como un caso especial de alteración fraudulenta de los precios naturales.

Se trataría, por lo tanto, de un caso casi paradigmático de derogación parcial y tácita.

\footnotetext{
${ }^{39}$ Este sistema, al que luego se le agregó la Fiscalía Nacional Económica pervivió en su estructura básica en el Decreto Ley $\mathrm{N}^{\circ}$ 211, mientras los acuerdos de precios se consideraban infracciones penales, esto es, hasta la entrada en vigencia de la Ley $\mathrm{N}^{\circ}$ 19.911, de 2003, que despenalizó estos hechos, sometiéndolos exclusivamente a la jurisdicción del Tribunal de la Libre Competencia.

${ }^{40}$ Diario de Sesiones de la Cámara de Diputados, Sesión 29a , lunes 26 de enero de 1959, p. 1667.
} 
Pero, además, si se mira el conjunto de la regulación de la Ley $\mathrm{N}^{\mathrm{o}} 13.305$, como un derecho nuevo y singular que regulaba toda la materia relativa a los atentados contra la libre competencia, podrá convenirse que aún cuando se sostuviese que las regulaciones en juego no eran incompatibles, esta Ley de 1959 vino a derogar orgánicamente todas las normas particulares y dispersas que pudieran referirse a los atentados contra la libre competencia, como sería el artículo 285 del Código penal en la parte en que, de conformidad con la hipótesis retórica con que trabajamos, sancionaría la conducta consistente en acordar precios, hecho prototípicamente atentatorio contra la libre competencia.

Todo lo cual se ve refrendado, además, por la literalidad del artículo 181 de la Ley $\mathrm{N}^{\circ}$ 13.305, cuyo contenido fue ampliamente discutido por los legisladores, en orden a determinar qué normas relativas a los monopolios dejarían expresamente subsistentes tras su promulgación. De donde se desprende, a contrario sensu, que aquellas disposiciones cuya vigencia no fue refrendada explícitamente, debían entenderse derogadas, de conformidad con los principios generales recién analizados.

Pues bien, la sola lectura de este artículo 181 lleva a la conclusión que, en ningún caso, fue la voluntad del legislador ni de la propia ley, dejar subsistente la eventual sanción penal de los acuerdos de precios bajo la norma general del artículo 285 del Código penal de 1874, que no es mencionada entre las normas que expresamente se dejan vigentes.

El artículo en cuestión dispone:

“Artículo 181. No obstante los preceptos de este Título, continuarán vigentes en todas sus partes las disposiciones legales y reglamentarias referentes a la Minería, especialmente el petróleo, a la producción, comercio y distribución del salitre, yodo y cobre; las contenidas en el Código Sanitario; las referentes a alcoholes y las que regulan la creación y funcionamiento de las empresas de servicios públicos o municipales; las relativas a empresas bancarias, de seguros, de reaseguros y bolsas de valores, como también las que digan relación con los transportes, fletamentos y cabotaje, ventas al martillo y crédito prendario.

Igualmente quedarán en vigor todas las disposiciones legales y reglamentarias que confieren a las autoridades atribuciones relacionadas con el ejercicio de actividades económicas o industriales, incluso aquellas que se refieren a la fijación de precios máximos a los artículos de primera necesidad y control de su cumplimiento."

- Imposibilidad del "resurgimiento" de una ley desplazada, cuando se pasa a llevar una disposición derogatoria expresa y un privilegio indudablemente establecido por el legislador.

Quienes, contra la historia fidedigna de su establecimiento y el texto del tipo penal respectivo, sostienen que el Artículo 285 del Código penal sí contempla el acuerdo de precios como un caso de "medio fraudulento" para alterarlos, también afirman, contra el texto expreso de la norma antes citada del Artículo 181 de la Ley $\mathrm{N}^{\mathrm{o}}$ 13.305, que ésta habría dejado subsistente la supuesta regulación del Código penal que dicen aplicable, alegando que en esta ley así como en el D.L. № 211 que le sucedió, sólo se contemplaría un caso "especial" del Artículo 285, que no habría derogado, en esa parte, la regulación de la ley anterior, sino que la habría dejado subsistente como "ley general" que, ahora, 
MATUS, Jean Pierre. “Acerca de la actual falta de punibilidad en Chile de los acuerdos de precios".

derogado el delito de acuerdo de precios del D.L. No 211, "resurgiría" y sería, por lo tanto, plenamente aplicable ${ }^{41}$.

Este supuesto argumento, sin embargo, no puede aceptarse por varias razones. Primero, porque contraviene el texto expreso del Artículo 181 de la Ley $N^{\circ}$ 13.305. Segundo, porque confunde los casos de concurso aparente de leyes de vigencia simultánea (como sería el típico ejemplo de la regulación del parricidio y el infanticidio frente al homicidio) con los casos de sucesión de leyes incompatibles, donde operan las reglas de derogación expresa y tácita. Y tercero, porque contra la doctrina inmensamente mayoritaria en Alemania y España y la única que se ha pronunciado expresamente sobre el tema del resurgimiento de la ley desplazada entre nosotros, sostiene que puede "resurgir" una ley contra la expresa voluntad del legislador de establecer un claro privilegio que, nos guste o no en sus efectos, ha sido clara y conscientemente creado por el legislador al derogar las figuras penales que castigaban los acuerdos de precios (abiertos y secretos) del D.L. No 211 . De este modo, se pasa a llevar lo dispuesto en el Artículo 18 del Código penal que exige atenerse a la nueva ley cuando esta ha eximido de toda pena un hecho y, consiguientemente, el principio de legalidad constitucionalmente consagrado.

Como ya dijimos, distinto es, en cambio, el caso de una ley que contemple simultáneamente figuras genéricas y especiales, donde no exista una regla de derogación expresa o tácita aplicable, sino la aplicación de una norma concursal (el principio de especialidad) como sucede típicamente en nuestro Código penal con las figuras del parricidio y el homicidio: una futura derogación de los delitos de parricidio no significará que esos hechos hoy en día especialmente penados, no podrán ser sancionados con la regla general que sanciona el delito de homicidio, aunque hoy en día sea desplazada en su aplicación por el principio de especialidad. Aquí estamos ante dos normas de vigencia simultánea y, además, compatibles (lo que permite, entre otras cosas, la división del título entre autores y partícipes sin vínculo especial), ninguna de las cuales ha derogado a la otra. Pero la doctrina mayoritaria en Alemania y España que acepta este resurgimiento, en ningún caso lo acepta cuando con ello se pasa a llevar una regla que atribuye a personas determinadas la facultad de iniciar o no un proceso penal mediante querella o denuncia, pues con ello tal requisito quedaría anulado de facto; ni tampoco cuando se pasa a llevar un privilegio, como sería precisamente el caso de imponer pena o imponer una pena más grave a un hecho particular que el legislador especialmente ha tenido en cuenta para despenalizarlo o privilegiarlo, respectivamente ${ }^{42}$.

\subsection{Consolidación institucional del sistema de protección penal y administrativa de la libre competencia: el Decreto Ley $\mathbf{N}^{0} 211$.}

Como es sabido, el Decreto Ley No 211, de 22 de diciembre de 1973, teniendo presente "que las normas destinadas a fomentar la libre competencia industrial y comercial que prevé el título $\mathrm{V}$ de la ley $\mathrm{N}^{\mathrm{o}} 13.305$, modificado por la ley $\mathrm{N}^{\mathrm{o}} 15.142$ [que estableció por

\footnotetext{
${ }^{41}$ HERNÁNDEZ, "La punibilidad”, cit. nota ${ }^{\circ} 29$, p. 158.

${ }^{42}$ Ver con detalles y referencias bibliográficas: MATUS A., Jean Pierre El Concurso aparente de leyes, Santiago: Ed. Jurídicas de Santiago, 2008, pp. 122-124 y 273-277. Véase también, DEL MISMO: Revista de Derecho (U. Católica de Coquimbo), No 9 (2002), pp. 27-68.
} 
primera vez un funcionario semejante a la Fiscalía en la materia], si bien tienen mérito conceptual no contemplan una estructura orgánico-funcional que las haga operativas y eficaces en todo el país" ( $\left.\mathrm{N}^{\mathrm{o}} 5^{\circ}\right)$, derogó dicho cuerpo legal (artículo cuarto transitorio), consolidando un sistema de protección de la libre competencia administrativo y penal a la vez, mediante el establecimiento de un nuevo órgano encargado de la investigación preliminar de los hechos atentatorios contra la libre competencia, la Fiscalía; y nuevas Comisiones Preventivas Provinciales (posteriormente, Regionales) y Central; así como el reemplazo de la antigua "Comisión" por una "Comisión Resolutiva", ahora con facultades sancionadoras de carácter administrativo propias.

Sin embargo, en lo "conceptual", y con referencia exclusiva a la tipificación penal de los acuerdos de precios atentatorios a la libre competencia, la situación no se alteró demasiado, tal como lo anunciaban los considerandos del mencionado Decreto Ley N 211.

En efecto, ahora la tipificación del delito contra la libre competencia se depuraba del casuismo de su antecesora, reduciéndose a castigar con presidio menor en cualquiera de sus grados al "que ejecute o celebre, individual o colectivamente, cualquier hecho, acto o convención, que tienda a impedir la libre competencia en la producción o en el comercio interno o externo" (artículo $1^{\circ}$ ), considerando su artículo $2^{\circ}$ como "actos o convenciones" de esa naturaleza, "los que se refieran a la determinación de los precios de bienes y servicios, como acuerdos o imposición de los mismos a otros” (letra d).

En cuanto al castigo penal de las personas jurídicas, se elimina la mención a la reincidencia y se establece una disposición especial para el caso de ser responsables del delito sociedades anónimas extranjeras (artículo cuarto).

Como ya mencionamos, la principal novedad de este cuerpo legal consistió en el establecimiento de un importante sistema orgánico encargado de la prevención, investigación y persecución de los atentados a la libre competencia y su represión, compuesto por las mentadas Comisiones Preventivas Provinciales (posteriormente Regionales) y Central, la Fiscalía y la Comisión Resolutiva (artículo $6^{\circ}$ ), organismo este último que vino a reemplazar en sus funciones a la "Comisión" del artículo 175 de la Ley $\mathrm{N}^{\mathrm{o}}$ 13.305, y estaba compuesta por un similar grupo de autoridades, a las que se agregaban el Director Nacional de Industria y Comercio, el de Impuestos Internos y el Síndico General de Quiebras (artículo 16). Esta nueva Comisión Resolutiva pasa a tener facultades sancionadoras de carácter administrativo en el conocimiento, "a requerimiento del Fiscal", de "las situaciones que pudieren importar infracciones al presente decreto ley" (artículo 17). Entre estas facultades sancionadoras administrativas se cuentan las de poner término a los actos o contratos contrarios a la libre competencia, declarar ciertas inhabilidades, ordenar la modificación o disolución de sociedades y aplicar multas. Junto a estas nuevas facultades, la Comisión Resolutiva conserva la de la anterior Comisión en cuanto a la facultad de poner en marcha el proceso penal, ahora expresada en la potestad de "ordenar al Fiscal el ejercicio de la acción penal respecto de los delitos a que se refieren los artículos $1^{\circ}$ y $2^{\text {or }}$ (artículo 17, $\mathrm{N}^{\mathrm{o}}$ 5). 
MATUS, Jean Pierre. “Acerca de la actual falta de punibilidad en Chile de los acuerdos de precios".

Requerido el ejercicio de la acción penal por parte de la Comisión Resolutiva, se mantiene como requisito especial de procesabilidad la presentación de una querella o denuncia, ahora por el Fiscal, quien puede actuar por sí o por delegado en el proceso (artículos $31 \mathrm{y}$ 32), bajo un procedimiento similar al ya establecido por la ley $\mathrm{N}^{\mathrm{o}} 13.305$ (apreciación de la prueba en conciencia; un Ministro de Corte de Apelaciones como Tribunal de instancia); pero con mayores facultades de investigación tanto para el Juez como para el Fiscal (artículos 33 a 37 y 23).

Finalmente, y al igual que ocurría con la Ley $\mathrm{N}^{\mathrm{o}}$ 13.035, para disipar toda duda de regulación, se estableció una regla derogatoria general, mediante la técnica de dejar subsistentes las disposiciones que expresamente indica, derogando así las no mencionadas y relativas a la misma materia. ${ }^{43}$

En resumen, sin alterarse significativamente el sistema de persecución penal de los delitos contra la libre competencia, consistentes en acuerdos de precios que tiendan a limitarla, el Decreto Ley $\mathrm{N}^{\mathrm{o}} 211$ al consolidar la institucionalidad protectora, le confirió a la Fiscalía y las Comisiones Preventivas y Resolutiva facultades para sancionar administrativamente las mismas conductas constitutivas del delito y ejercer, discrecionalmente, la acción penal a su respecto. Se dio comienzo así al proceso de administrativización de las conductas contrarias a la libre competencia, el que culminaría con la dictación de la Ley No 19.911.

De esta realidad normativa, en que los hechos de la llamada "colusión" o acuerdos de precios contrarios a la libre competencia sólo se encontraban regulados en el Decreto Ley $\mathrm{N}^{\mathrm{o}}$ 211, con sanciones tanto administrativas como penales, previo requerimiento de la Comisión Resolutiva, da cabalmente cuenta el Oficio del Fiscal Nacional del Ministerio Público sobre "Investigación de los Delitos Contenidos en la Ley Antimonopolios", donde se señala que, "el hecho, acto o convención atentatorio contra la competencia no es una figura estrictamente penal, sino que constituye principalmente un ilicito administrativo," por lo que sólo la finalidad de impedir la libre competencia, sumada al hecho objetivo, podría dar lugar a un delito, aunque reconoce que ha sido escasamente perseguido, siendo privativa de la Comisión Resolutiva la decisión de requerir o no el ejercicio de la acción penal, transformándose así estos delitos en aquellos “de acción pública, previa instancia particular". Como era de esperarse, en ninguna parte de este Oficio se instruye de manera

43 "Artículo 5 . Sin perjuicio de lo establecido en el presente decreto ley, continuarán vigentes las disposiciones legales y reglamentarias referidas a las propiedades intelectual e industrial, a la minería, especialmente al petróleo, a la producción, comercio y distribución del salitre, yodo y cobre; las contenidas en el Código Sanitario; las contempladas en la Ley de Alcoholes y Bebidas Alcohólicas; las que regulan la creación y funcionamiento de las empresas de servicios públicos o municipales; las relativas a empresas bancarias, de seguros, de reaseguros y bolsas de valores; como también las que digan relación con los transportes, fletamentos y cabotajes, ventas al martillo y crédito prendario.

Igualmente quedarán en vigor las disposiciones legales y reglamentarias que confieren a las autoridades atribuciones relacionadas con el ejercicio de las actividades económicas, incluso aquellas que se refieren a la fijación de precios máximos y control de su cumplimiento.

Con todo, no podrá establecerse ningún estanco, ni aún en virtud de los preceptos referidos en los dos incisos precedentes sin previo informe favorable de la Comisión Resolutiva.

La Comisión Resolutiva podrá requerir la modificación o derogación de los preceptos señalados en este artículo en cuanto, limitando o eliminando la libre competencia, los estime perjudiciales para el interés común." 
Polít. crim. Vol. 7, No 14 (Diciembre 2012), Art. 3, pp. 318 - 356.

[http://www.politicacriminal.cl/Vol_07/n_14/Vol7N14A3.pdf]

general el ejercicio de la acción penal en relación con los artículos 285 o 473 del Código punitivo, para los casos en que alguna de las instituciones del sistema del Decreto Ley $\mathrm{N}^{\mathrm{o}}$ 211 no ejerciese sus facultades o, requerida la acción penal por ese cuerpo legal, fuese por cualquier motivo imposible seguir con ella. Al contrario, el Oficio reseñado reafirma que, respecto a estos hechos, la acción penal pública sólo podía ejercerse después de la investigación administrativa y sólo a requerimiento de la Comisión Resolutiva. ${ }^{4}$

3.3.1. La situación legal tras la dictación del Decreto Ley $N^{\circ} 211$, el año 1974. Mantención de la regla derogatoria que no deja subsistente el Código penal.

De lo recién expuesto, resulta más o menos evidente que al dictarse este Decreto Ley $\mathrm{N}^{\circ}$ 211 no existía la intención de devolverle su vigor al artículo 285 del Código penal de 1874 en la parte que sancionaría los acuerdos de precios (según la interpretación errónea que aquí se rechaza), pues éstos se consideraban un caso especial de atentado contra la libre competencia, sometido al régimen, también especial, de prevención y sanción de dicho Decreto Ley.

Ello explica por qué, en su artículo $5^{\circ}$, al determinarse expresamente las normas relativas a los monopolios cuya vigencia subsistiría tras la dictación de este Decreto Ley, sencillamente se reprodujo en buena parte el artículo 181 de la Ley $\mathrm{N}^{\circ} 13.305$ que se derogaba en ese acto, agregando la necesidad de un acuerdo de la Comisión Resolutiva para el establecimiento de nuevos estancos de conformidad con las facultades que se declaraban subsistentes. Pero, al igual que en el artículo 181 de la Ley $\mathrm{N}^{\circ} 13.305$, no se devolvió expresamente en su vigor la disposición del artículo 285 del Código penal, en cuanto sancionaría el acto contrario a la libre competencia consistente en acordar los precios de venta entre varios proveedores.

Por lo tanto, el Decreto Ley $\mathrm{N}^{\circ} 211$ mantuvo la derogación del artículo 285 del Código penal en la parte que sancionaría como alternación fraudulenta de los precios naturales el acuerdo de precios entre proveedores.

\subsection{Despenalización de las conductas contrarias a la libre competencia, y en particular, de los} acuerdos de fijación de precios: la Ley $\mathbf{N}^{0}$ 19.911, de 14 de noviembre de 2003.

En un artículo aparecido el año 1997, el entonces Abogado Asesor de la Fiscalía Nacional Económica, Sr. Radoslav Depolo Razmilic, afirmaba que "no aparece apropiado, en una etapa de madurez del sistema económico chileno, utilizar normas penales para su protección", pues

"la economía nacional es una de las más abiertas y competitivas del mundo; no existen barreras de peso a la entrada o salida de nuevos competidores, sean nacionales o extranjeros; y el empresario está consciente de que el Estado cumple una labor fiscalizadora respecto de aquellos actos que atenten o puedan atentar contra la libre

\footnotetext{
${ }^{44}$ El oficio citado se encuentra impreso en el texto MINISTERIO PÚBLICO, FISCALÍA NACIONAL. Reforma procesal penal. Oficios del Fiscal Nacional en materias penales. 2001-2004. Santiago: Ed. Jurídica de Chile, 2005, 488 pp., pp. 225-249.
} 


\section{MATUS, Jean Pierre. “Acerca de la actual falta de punibilidad en Chile de los acuerdos de precios".}

competencia. A estas alturas -agregaba el asesor del Fiscal Nacional Económico-, los fines de protección que persigue el DL 211 pueden obtenerse por la sola aplicación de su faz administrativa sancionatoria, y no por el ejercicio de la acción penal". 45

Recogiendo esta propuesta, y como ya hemos en parte transcrito, el Mensaje Presidencial No 132-346 con el se inició el Proyecto de Ley que creó el Tribunal de Defensa de la Libre Competencia, de 17 de mayo de 2002, planteaba entre sus objetivos, aparte de las reformas orgánicas que ello suponía, la despenalización total y absoluta de las conductas contrarias a la libre competencia, tanto por razones de técnica legal (la dificultad de conciliar una regulación amplia con el principio de legalidad), como de eficacia (la aparente falta de fuerza disuasoria de las sanciones penales en la materia, en comparación con la que tendrían las fuertes multas que se proyectaban). Para evitar cualquier duda de interpretación al respecto, transcribiré a continuación la parte pertinente del Mensaje aludido:

\section{"III. 3. Eliminación del carácter penal.}

Todo tipo penal debe describir las conductas que sanciona de manera precisa, de forma que los sujetos a los cuales se dirige la norma tengan la certeza de aquello que está prohibido por el legislador.

Sin embargo, el escenario actual en el que se desenvuelven los agentes económicos es complejo, por lo que es importante no introducir reglas que señalen per se las conductas que constituyen atentados en contra de la libre competencia. La experiencia mundial indica que hoy que cada caso debe ser estudiado en su propio mérito, de acuerdo con sus complejidades y particularidades. Por estos motivos, resulta aconsejable mantener una norma amplia con ejemplos básicos, para que los integrantes del organismo encargados de conocer las causas decidan, de acuerdo al caso concreto, qué conducta constituye un atentado a la libre competencia.

Sin embargo, este enfoque es incompatible con la existencia de una figura penal, en la cual la especificación del tipo es un requisito ineludible, so pena de vulnerar la garantía constitucional establecida en el inciso final del número 3 del artículo 19 de nuestra Constitución.

Como contrapartida a la eliminación del carácter penal, que rara vez ha dado paso a la acción penal y se estima que no ha logrado disuadir las conductas contra la libre competencia, se propone aumentar las multas y hacer responsables solidariamente de su pago a los directores, gerentes o administradores de las empresas que incurrieren en ellas.”

En conformidad con lo anterior, habrá que entender que el colegislador consideró al menos poco eficaz sancionar penalmente la conducta que describía en el proyectado nuevo Artículo $3^{\circ}$ letra a) del Decreto Ley $N^{\circ} 211$, consistente en celebrar o ejecutar "acuerdos

\footnotetext{
${ }^{45}$ DEPOLO RAZMILIC, Radoslav, "El régimen jurídico de defensa de la competencia en Chile. Algunas proposiciones para su despenalización", Revista de Derecho de la Universidad Católica de Valparaíso, t. XVIII (1997), pp. 435-441, p. 439. Y añade, desde el punto de vista empírico, lo siguiente: en un universo de más de dos mil causas, "la acción penal contemplada en el DL 211 ha sido ejercida en dos ocasiones, en ninguna de las cuales llegó a prosperar".
} 
Polít. crim. Vol. 7, No 14 (Diciembre 2012), Art. 3, pp. 318 - 356.

[http://www.politicacriminal.cl/Vol_07/n_14/Vol7N14A3.pdf]

expresos o tácitos entre agentes económicos, o las prácticas concertadas entre ellos, que tengan por objeto fijar precios de venta o de compra, limitar la producción o asignarse zonas o cuotas de mercado", prefiriendo entregar su prevención y sanción al Tribunal de la Libre Competencia y a la Fiscalía Nacional Económica, particularmente con las importantes sanciones pecuniarias establecidas en el que terminó por ser el actual artículo 26 del Decreto Ley $\mathrm{N}^{\mathrm{o}}$ 211, según el Texto refundido del mismo, promulgado por el Decreto con Fuerza de Ley $N^{0} 1$ de Economía, publicado en el Diario Oficial de 7 de marzo de 2005.

Desde luego, así lo entendió también el Centro de Estudios Libertad y Desarrollo, vinculado a los entonces partidos políticos de oposición. En un extenso informe sobre el contenido del Proyecto de Ley de marras, se señala, respecto de la eliminación del carácter penal de estas conductas, que "la eliminación es positiva", pues

"No es adecuado sancionar infracciones económicas con las propiamente penales, sino
que con castigos de carácter también económico, que operan como forma de
desincentivar las conductas. Además hay que considerar que muchas veces las
situaciones son discutibles y poco claras, dado lo complejo de los escenarios
comerciales." 46

Durante la tramitación el Proyecto, tampoco se puso en duda la despenalización operada.

Así, en su Informe preceptivo, la Exma. Corte Suprema da cuenta de esta despenalización, pero no hace observación particular alguna. ${ }^{47}$ En la discusión habida en la Comisión de Economía de la H. Cámara de Senadores, al elaborarse el Primer Informe de la tramitación correspondiente, el entonces Ministro de Economía, insistió en la eliminación del carácter penal de estas conductas, citando

"el mensaje que acompaña al proyecto, donde ya se dijo que el carácter penal es incompatible con una ley en la que difícilmente se puede tipificar el delito de conducta monopólica, por la naturaleza dinámica de las conductas anticompetitivas. Además, se dijo que la normativa penal no ha funcionado como un buen inhibidor de conductas anticompetitivas, porque prácticamente nunca se ha recurrido a la acción penal, ${ }^{48}$

Lo cual fue aprobado en general por los Senadores concurrentes. Al pasar a discutirse el Proyecto en la Comisión de Hacienda del Senado, el entonces Subfiscal Nacional Económico, don Enrique Vergara, reiteró que en él

"se eliminan las penas privativas de libertad que consagra la actual legislación, por dos razones, la primera, jurídica, ya que se ha estimado que esta norma contenía una ley

\footnotetext{
${ }^{46}$ DOMPER, $\mathrm{M}^{\mathrm{a}}$ de la Luz; BUCHHEISTER, Axel, Tribunal de la Competencia: Modificaciones a la institucionalidad antimonopolio en Chile. Serie Informe Económico $\mathrm{N}^{\circ} 133$. Santiago: Instituto Libertad y Desarrollo, 2002, 42 pp., p. 38.

${ }^{47}$ Historia, cit. nota ${ }^{\circ} 1$, p. 32 .

${ }^{48}$ Historia, cit. nota $\mathrm{n}^{\circ} 1$, p. 53 .
} 
MATUS, Jean Pierre. “Acerca de la actual falta de punibilidad en Chile de los acuerdos de precios".

penal en blanco, $\mathrm{y}$, otra, práctica, puesto que en los últimos treinta años nunca se ha aplicado esta norma."49

Al pasar el Proyecto a discutirse en la Cámara de Diputados, en su comparecencia ante las Comisiones Unidas de Constitución, Legislación y Justicia y de Economía, Fomento y Desarrollo, Don Jorge Streeter Prieto, abogado, profesor de Derecho Económico de la Universidad de Chile, señaló, reafirmando lo sostenido por el Mensaje, que "en el caso chileno y desde el punto de vista penal, el llamado delito de monopolio ha sido enteramente ineficaz y nunca nadie ha sido castigado por cometerlo", agregando que

“ello no se debía a que jamás se hubiera incurrido en una conducta monopólica o en una colusión ilícita, sino que al hecho de que los órganos del Estado llamados a aplicar la ley, nunca han estimado del caso tratarla como una verdadera ley penal, considerándola como propia del ámbito económico, en que incluso las infracciones más graves, no merecen la sanción prevista en la ley." 50

A partir de este momento no se hizo mayor cuestión, durante la tramitación parlamentaria, de la despenalización de las conductas contrarias a la libre competencia que el Proyecto de ley proponía sancionar de manera exclusiva por la vía administrativa, en un procedimiento especial a cargo de la Fiscalía Nacional Económica y el Tribunal de la Libre Competencia que se creó con la entrada en vigor de la Ley $\mathrm{N}^{0} 19.911$.

Por lo tanto, no cabe sino concluir que nuestro Congreso Nacional hizo suyos los planteamientos del Mensaje Presidencial correspondiente, despenalizando de manera total y absoluta las conductas que pudieran calificarse de contrarias a la libre competencia y, en particular, las ejemplificadas en el artículo $3^{\circ}$ letra a) del decreto Ley $\mathrm{N}^{\mathrm{o}} 211$, a saber, "los acuerdos expresos o tácitos entre agentes económicos, o las prácticas concertadas entre ellos, que tengan por objeto fijar precios de venta", pues, en conformidad con la actual redacción del inciso segundo del artículo $1^{\circ}$ de este cuerpo legal, "los atentados contra la libre competencia en las actividades económicas serán corregidos, prohibidos o reprimidos en la forma y con las sanciones previstas en esta ley", la cual no contempla para ellos sanciones penales de ninguna especie.

3.4.1. La situación legal tras la despenalización de los acuerdos de precios, de conformidad con la Ley $\mathrm{N}^{\circ} 19.911$, de 14 de noviembre de 2003. La incompatibilidad absoluta de la despenalización con la aplicación del Artículo 285 Código penal y la consecuente prohibición de su supuesto "resurgimiento".

De conformidad con lo antes explicado, la historia fidedigna del establecimiento de la Ley $\mathrm{N}^{\mathrm{o}} 19.911$ y las modificaciones que introdujo al Decreto Ley $\mathrm{N}^{\mathrm{o}} 211$ indican su inequívoco propósito de despenalizar las conductas atentatorias contra la libre competencia, entre las cuales se encuentran "los acuerdos de precios" ("abiertos" o "cerrados", pues la ley no

\footnotetext{
${ }^{49}$ Historia, cit. nota ${ }^{\circ} 1$, p. 246.
}

${ }^{50}$ Historia, cit. nota $\mathrm{n}^{\circ} 1$, p. 321 . 
Polít. crim. Vol. 7, No 14 (Diciembre 2012), Art. 3, pp. 318 - 356.

[http://www.politicacriminal.cl/Vol_07/n_14/Vol7N14A3.pdf]

hace distinción alguna al respecto), entregando su prevención y sanción a los organismos administrativos que allí se establecen.

Por lo tanto, en este caso se produce una incompatibilidad absoluta entre la Ley $\mathrm{N}^{\mathrm{o}} 19.911$, de 2003, posterior y especial, que despenaliza expresamente los acuerdos de precios entre proveedores y el artículo 285 del Código penal de1874, si se entendiera que éste penaliza desde el siglo XIX dichos acuerdos de precios como una forma de alteración fraudulenta de los precios naturales de las mercancías.

Esta incompatibilidad absoluta entre una ley posterior y especial (el Decreto Ley $\mathrm{N}^{\mathrm{o}} 211$, de 1974, reformado por la Ley $\mathrm{N}^{0}$ 19.911, de 2003) y otra anterior (el artículo 285 del Código penal de 1874), produciría de por sí el efecto de derogar tácitamente la ley anterior, si se llegase a afirmar que ésta, a pesar de lo dicho anteriormente, de todos modos continuaba vigente en el año 2003, sancionando penalmente los acuerdos de precios entre proveedores, hechos que el legislador de 2003 indubitablemente ha querido sustraer de la jurisdicción criminal. De este modo, el supuesto "resurgimiento" del Artículo 285 del Código penal pasaría a pasar a llevar no sólo los expresos privilegios procesales y sancionatorios concedidos, sino el propio principio de legalidad, al aplicarse una pena a un hecho expresamente exento de la misma.

Por otra parte, en la nueva redacción que se ha dado al Decreto Ley $\mathrm{N}^{\mathrm{o}} 211$ de 1974, se ha suprimido su anterior artículo $5^{\circ}$, que mantenía en vigor ciertas disposiciones (pero no el artículo 285 del Código penal), agregándose un nuevo artículo $5^{\circ}$ transitorio que dispone:

“Artículo 5.- Deróganse las disposiciones del Título V de la ley N¹3.305.

Declárase que las conductas comprendidas en los hechos constitutivos de delito con arreglo a lo establecido en los artículos $1^{\circ}, 2^{\circ}$ y $3^{\circ}$ de esta ley, según el texto original del decreto ley $\mathrm{N}^{\circ} 211$, de 1973 , realizadas con anterioridad a la vigencia del citado cuerpo legal, no serán susceptibles de ser sancionadas en conformidad con lo expresado en los referidos preceptos, ni, tampoco, de acuerdo a lo que estatuía el Título V de la ley $\mathrm{N}^{\circ} 13.305$, derogado por el inciso anterior de este artículo, sin perjuicio de lo dispuesto en el artículo $1^{\circ}$ transitorio."

Es decir, se establece expresamente un privilegio para las conductas monopolísticas, y particularmente la celebración de convenciones para fijar precios, entendidas anteriormente como delitos por la Ley No 13.305 y el Decreto Ley No 211 de 1974, según el cual, éstas ya no son delitos, esto es, no pueden ser sancionadas penalmente, sino sólo administrativamente.

De donde no es posible, sin infracción a lo preceptuado por el artículo $19 \mathrm{~N}^{\mathrm{o}} 3$, inciso $8^{\circ}$, pretender el castigo del acto atentatorio contra la libre competencia consistente en celebrar acuerdos sobre precios, despenalizado expresamente por una norma del año 2003, mediante el expediente de hacerle también aplicable una norma como la del artículo 285 del Código penal de 1874, que si comprendiera dicho caso como una forma de alteración fraudulenta de los precios naturales, estaría derogada tácita y orgánicamente en dicha parte por la Ley $\mathrm{N}^{\mathrm{o}} 13.305$ de 1959 , sin haber recobrado jamás su vigencia por alguna norma legal que así lo estableciera. 
MATUS, Jean Pierre. “Acerca de la actual falta de punibilidad en Chile de los acuerdos de precios".

\section{El futuro: la reciente modificación del Decreto Ley $\mathrm{N}^{\mathrm{a}} 211$ y los proyectos de ley que tienden a restituir el carácter delictivo de las conductas de "colusión" o acuerdos de precios.}

\subsection{Modificación del Decreto Ley $\mathbf{N}^{\circ} 211$ por la Ley $\mathbf{N}^{\circ} 20.361$.}

Recientemente se ha publicado la Ley No 20.361 (Diario oficial de 13 de julio de 2009), que introdujo modificaciones puntuales a la versión del Decreto Ley $\mathrm{N}^{\mathrm{o}} 211$, contenida en el Decreto con Fuerza Ley $\mathrm{N}^{\circ} 1$ de Economía de 2005. Ninguna de estas modificaciones restableció el carácter penal de las conductas descritas en su artículo $3^{\circ}$, letra a), que se modifica únicamente para agregar un nuevo requisito a su descripción, en el sentido de habilitar la sanción administrativa de "los acuerdos expresos o tácitos entre competidores, o las prácticas concertadas entre ellos, que les confieran poder de mercado y que consistan en fijar precios de venta etc."

La sola lectura de esta nueva redacción de la disposición que describe el acuerdo de precios, denota que ella exige ahora (más precisamente, a partir del 11 de octubre de 2009, fecha a la que está diferida su vigencia) que el acuerdo produzca el resultado de conferirle a los concurrentes "poder de mercado". Cuándo y en qué condiciones podrá demostrarse en juicio este nuevo requisito no es materia de esta investigación, sino sólo resaltar aquí que esta significativa modificación no importó otorgarle un carácter penal a estas conductas.

\subsection{Las mociones parlamentarias y la indicación del Ejecutivo para establecer nuevamente la punibilidad de hechos que atenten contra la libre competencia y, particularmente, para la ahora llamada "colusión" de precios.}

El Boletín No 6438-03 contiene una moción de los H. Diputados Srs. Accorsi, Farías, Guirardi, Leal, Núñez, Saa, Silber, Vallespín y Vidal, que propone sencillamente restablecer como delito las conductas descritas en el actual artículo $3^{\circ}$ del Decreto Ley $\mathrm{N}^{\mathrm{o}}$ 211, intercalando en el mismo una sanción corporal privativa de libertad y estableciendo para el Tribunal de la Libre Competencia la obligación de denunciar los hechos al Ministerio Público, una vez impuesta alguna de las sanciones administrativas prescritas en el artículo 26 de dicho cuerpo legal.

Entre sus fundamentos se reconoce que el carácter punible de los acuerdos de precios, comprendido en la original redacción del Decreto Ley $\mathrm{N}^{\mathrm{o}} 211$, fue eliminado al crearse el Tribunal de Libre Competencia, "es decir, por medio de esta nueva institucionalidad se cambiaron las sanciones para el caso de infracción a las normas que regulan la libre competencia ... con ello, se eliminaron las penas corporales para las personas que actuaron con infracción a estas normas" $\left(\mathrm{N}^{\circ} 2\right)$. Además, se advierte que la entonces en trámite modificación del Decreto Ley N 211 y ahora recientemente promulgada Ley № 20.361, pretende modificarlo

"perfeccionando y asegurando la independencia del Tribunal de la libre competencia, además otorga nuevos instrumentos de investigación para la Fiscalía nacional Económica, como por ejemplo la delación compensada, pero no insiste en darle 
Polít. crim. Vol. 7, No 14 (Diciembre 2012), Art. 3, pp. 318 - 356.

[http://www.politicacriminal.cl/Vol_07/n_14/Vol7N14A3.pdf]

carácter penal a las sanciones en contra de las personas que infrinjan las normas sobre libre competencia, aún en casos graves" ( $\left.\mathrm{N}^{\circ} 3\right)$.

Por lo anterior, los Diputados suscriptores de la Moción, concluyen que consideran

"necesario incorporar una norma penal para estos casos, para castigar a quienes pudieren urdir engaños masivos a la población por medio de la vulneración a las normas que regulan la libre competencia, ya que hoy sólo se podrían aplicar multas o modificaciones a las empresas y los ejecutivos a lo más, serán responsables del pago de las multas".

Agregando que

"no parece comprensible que se castigue con penas de prisión a quien robe o hurte una cartera o una joya y que se deje sin castigo penal a quienes puedan implementar engaños masivos, por medio de una aparente competencia comercial, y por otra mediante el engaño y el acuerdo oculto, obtener ganancias de miles de millones de pesos." ( $\left.\mathrm{N}^{\mathrm{o}} 5\right)$.

Por lo tanto, con independencia de la bondad de la propuesta, ha de tenerse por cierto que, a juicio de un importante grupo de legisladores que en su mayoría participaron en las discusiones y aprobación de los cuerpos legales que despenalizaron las infracciones contra la libre competencia, éstas infracciones, con independencia del juicio moral que a ellos les produce y del carácter de "engaño masivo" que le atribuyen, no se encuentran penalmente sancionadas en la actualidad.

Lo mismo cabe concluir de los fundamentos que ofrecen los H. Diputados Allende, de Urresti, Díaz, Encina, Espinoza, Montes, Paredes, Pascal, Rossi y Schilling en su moción ingresada en el Boletín $\mathrm{N}^{0}$ 6439-07, donde en su punto 4 se señala que la moción "tiene por objeto suplir un déficit en el Código Penal Chileno y otras leyes penales especiales, pues, no existen los delitos contra los intereses de los consumidores y la libre competencia" (el resaltado es nuestro). Sin embargo, a esta categórica afirmación se agrega que

"una eventual intervención penal en esta materia queda condicionada a subsumir los hechos que configuran atentados contra los intereses difusos de los consumidores en alguno de los tipos penales que tutelan el patrimonio u otros bienes jurídicos (v. gr. el artículo 467 o el numeral 1 del artículo 469 del Código Penal), u otros bienes jurídicos, como los delitos contra la industria y el comercio o asociación ilícita (artículo 285, 286 y 292 del C. Penal).”

Al respecto, cabe señalar que, como se demostró en el punto $\mathrm{N}^{\mathrm{o}} 1$ de este texto, el mentado artículo 285 del Código penal no sanciona la coligación o acuerdo de precios, sino una maquinación dolosa (fraude) que produzca engaño o error en un tercero. Por lo mismo, el acuerdo de precios no es punible ni conforme a esa disposición ni a la del artículo 286, que establece un comiso como sanción adicional en un caso especial del delito del artículo 285.

Lo anterior queda meridianamente claro de la lectura de la indicación sustitutiva a las dos mociones recién reseñadas, suscrita por la Exma. Sra. Presidenta de la República y los Srs. 
MATUS, Jean Pierre. “Acerca de la actual falta de punibilidad en Chile de los acuerdos de precios".

Ministros de Economía, Justicia y Hacienda, No 479-357, de 10 de junio de 2009. En efecto, allí se señala entre sus antecedentes que

"el gran impacto que ha generado el caso de la colusión de precios de las cadenas farmacéuticas más importantes del mercado, ha demostrado la necesidad de reestablecer un tipo penal específico que sancione penalmente las conductas que verifican la hipótesis descrita en la letra a) del inciso segundo del artículo $3^{\circ}$ del decreto con fuerza de ley $\mathrm{N}^{\circ} 1$ del Ministerio de Economía, Fomento y Reconstrucción, publicado el año 2005, que fija el texto refundido, coordinado y sistematizado del decreto ley $\mathrm{N}^{\circ} 211$ de 1973, referido a la colusión, cuando se cometan con la finalidad de afectar actividades económicas consideradas esenciales."

Luego, se reitera que

"esta tipificación no se estableció en el proyecto de ley recientemente despachado por el Congreso, Boletín $N^{\circ} 4234-03$, pues sus ideas matrices tenían por objeto asegurar la independencia del Tribunal de Defensa de la Libre Competencia y otorgar nuevos instrumentos de investigación para la Fiscalía Nacional Económica."

Y se insiste en lo mismo que ya se ha afirmado aquí, es decir, que los hechos contrarios a la libre competencia, como podrían serlo ciertos acuerdos de precios (la "colusión"), se reprimen por la legislación vigente exclusivamente con sanciones de carácter administrativo y que el Código penal no contempla tipo penal alguno que sancione dichas conductas, no estando comprendidas en su artículo 285, a menos que vayan acompañadas de maquinaciones dolosas (fraudes) que induzcan a error o engaño.

Así, se afirma por quienes suscriben la indicación sustitutiva que

"La legislación en vigor no consagra un tipo penal específico para sancionar los casos en que los responsables de la gestión de los negocios se concierten para impedir, restringir o entorpecer la libre competencia, mediante un cartel o acuerdo colusorio. La necesidad de resolver este vacío ha quedado en absoluta evidencia a luz de los últimos acontecimientos vinculados a la colusión de precios desplegada por varios actores del mercado farmacéutico que se investiga por el Tribunal de Defensa de la Libre Competencia y que se puede señalar como tal, en virtud del acuerdo suscrito por una cadena de farmacias con la Fiscalía Nacional Económica, aprobado por dicho Tribunal."

\section{Agregando:}

"Además, se debe tener presente que las figuras actualmente contempladas en el Código Penal no se ajustan a cabalidad a la conducta desplegada por estos agentes, lo que impide que éstos sean eficazmente reprimidos en virtud de ese marco legal."

Luego, para suplir este "vacío", propone esta indicación sustitutiva agregar un nuevo artículo 285 bis al Código penal, que contemple expresamente como delito los hechos descritos en el artículo $3^{\circ}$, letra a) del Decreto Ley $\mathrm{N}^{\circ}$ 211, ahora sancionados administrativamente, agregándoles, para conferirles un carácter reprochable penalmente, el 
elemento subjetivo correspondiente a cometerlos con la "finalidad de afectar actividades económicas consideradas esenciales", convirtiendo el hecho en un delito de tendencia, conforme con lo propuesto hace ya más de 50 años don Eduardo Novoa M. ${ }^{51}$ Además, como en el régimen anterior, se propone que la acción penal por esta clase de delitos sólo pueda sostenerse previa querella presentada por el Fiscal Nacional Económico ante el Juez de Garantía competente, por lo que la acción penal pasa a tener un carácter de previa instancia particular o mixta, como requisito de procesabilidad.

La situación en el Senado es similar: con fecha 1 de abril de 2009, el Senador Zaldívar, "considerando los hechos de público conocimiento relacionados con la colusión celebrada entre cadenas de farmacias destinadas a fijar precios, alterando el funcionamiento normal del mercado"; y "teniendo presente que tales conductas dañan gravemente el orden público económico y los principios fundamentales de una sana economía social de mercado, afectando a miles de personas", sometió a la consideración del Honorable Senado una moción que introduce un nuevo artículo 32 bis al Decreto Ley $\mathrm{N}^{\mathrm{o}} 211$, que sanciona con pena privativa de libertad, las conductas contra la libre competencia en los mercados que indica. ${ }^{52}$ Siete días más tarde, se ingresó con similar propósito la moción de los Senadores Cantero, García y Horvath, quienes, después de reconocer expresamente que la Ley $\mathrm{N}^{\mathrm{o}}$ 19.911 eliminó el carácter penal de los acuerdos de precios ("colusión”) contrarios a la libre competencia, fundamentan su Proyecto argumentando que "a la luz de los acontecimientos recientes, creemos que es importante reestablecer la sanción penal, sólo para el caso de colusión" (el subrayado es nuestro). ${ }^{53}$

${ }_{51}^{51}$ NOVOA, "La legislación", cit. nota ${ }^{\circ} 2$, p. 166 y ss.

${ }^{52}$ Boletín $N^{\circ} 6.442-03$. El nuevo artículo 32 bis propuesto, dispondría:

"Artículo 32 bis. Los que en cualquier forma celebren, convengan, fomenten o ejecuten pactos, acuerdos, convenciones o declaraciones que tengan por finalidad precisa acordar o fijar precios de venta o de compra, límites de producción o de venta o asignarse zonas, partes o cuotas de mercado, alterando el funcionamiento natural de éste serán castigados con las penas de reclusión menor en su grado máximo.

Si las conductas descritas en el inciso precedente fueren realizadas por personas jurídicas a través de sus gerentes, mandatarios, trabajadores o asesores, sin perjuicio de castigar a los autores, cómplices o encubridores, tal persona jurídica quedará disuelta por el sólo ministerio de la ley, tan pronto se encuentre ejecutoriada la sentencia condenatoria de los sujetos señalados en este inciso".

${ }^{53}$ Boletín $\mathrm{N}^{\mathrm{o}}$ 6.454-07, de 8 de abril de 2009. Este Proyecto ha tenido un aparente mayor avance en su tramitación pues, atendido que contiene modificaciones orgánicas, se ha oficiado reglamentariamente y en cuenta, a la Corte Suprema, para que realice el informe preceptivo, antes de proseguir su tramitación. El texto del Proyecto de Ley es el siguiente:

"Artículo Primero.- Modifícase el DFL No 1, de 2004, del Ministerio de Economía, Fomento y Reconstrucción, que fija el texto refundido, coordinado y sistematizado del DL $N^{\circ} 211$, de 1973, de la siguiente forma:

Agrégase en el artículo $3^{\circ}$, el siguiente inciso final nuevo: "El que cometa la conducta señalada en la letra a) anterior, será sancionado con presidio menor en cualquiera de sus grados. En el caso que dicha conducta se realice a través de un sistema de telecomunicaciones al que se tenga acceso desde el territorio nacional, se entenderá cometida en Chile.".

Intercálase en el artículo $20^{\circ}$, el siguiente nuevo inciso tercero, pasando los actuales incisos tercero, cuarto, quinto y sexto, a ser, cuarto, quinto, sexto y séptimo, respectivamente: "En el caso que los hechos en que se fundamenta la demanda o el requerimiento sean constitutivos del delito señalado en el artículo $3^{\circ}$, el tribunal deberá enviar de inmediato los antecedentes al Ministerio Público".

Artículo Segundo.- Agrégase en el artículo $6^{\circ}$ del Código Orgánico de Tribunales, el siguiente numeral $11^{\circ}$ nuevo: " $11^{\circ}$ Los sancionados en el artículo $3^{\circ}$ del DFL $N^{\circ} 1$, de 2004, del Ministerio de Economía, Fomento y Reconstrucción, que fija el texto refundido, coordinado y sistematizado del DL $\mathrm{N}^{\mathrm{o}} 211$, de 1973, cuando 
MATUS, Jean Pierre. “Acerca de la actual falta de punibilidad en Chile de los acuerdos de precios".

Por lo tanto, es más o menos claro que tanto para los actores políticos de todos los sectores como para el Supremo Gobierno, las conductas consistentes en acuerdos de precios de venta contrarios a la libre competencia, no constituyen delito hoy en día y, por lo mismo, realizan distintas propuestas tendientes a volver a criminalizar aquellos hechos, despenalizados con la entrada en vigencia de la Ley $\mathrm{N}^{\mathrm{o}} 19.911$, de 14 de noviembre de 2003.

\section{Conclusiones.}

5.1. El artículo 285 del Código penal vigente no contempla, como modalidad típica, la "coligación" o acuerdo de precios, expreso o tácito, el que estima lícito. Para la existencia de un delito, en la forma prescrita por este artículo, se exige el despliegue de medios fraudulentos para inducir a engaño o error a alguno de los contratantes en la libre concurrencia de mercaderías;

5.2. Tampoco el artículo 473 del Código penal vigente contempla como engaño punible la oferta de un bien a un precio convenido por una parte de los proveedores, mediante un acuerdo expreso o tácito, si el precio ofrecido es conocido por el comprador y es el que efectivamente se cobra, pues en tales casos no existe engaño alguno. Los casos de maquinaciones fraudulentas para alterar los precios naturales, que no consistan en engaños a los compradores, deben reconducirse al artículo 285 de dicho cuerpo legal, el cual, como se dijo, no considera como tal los acuerdos expresos o tácitos de precios entre oferentes o demandantes.

5.3. El acuerdo de precios, expreso o tácito, sólo llegó a ser una conducta punible, previo requerimiento de una "Comisión" especial, cuando tendiera a impedir la libre competencia, recién en la nueva y singular regulación del artículo 175 la Ley $\mathrm{N}^{\circ} 13.305$, de 6 de abril de 1959, derogatoria de toda la legislación anterior que se refería a la materia y no se dejaba expresamente subsistente;

5.4. El Decreto Ley $N^{o} 211$ de 22 de diciembre de 1973 estableció un nuevo sistema sancionador de carácter administrativo de estas conductas, pero mantuvo en su artículo $2^{\circ}$, letra d), su punibilidad, si así lo decidía la "Comisión Resolutiva" que allí se estableció, en particular, cuando se referían a la determinación de los precios de bienes y servicios, como acuerdos o imposición de los mismos a otros, derogando de paso toda la legislación anterior que se refería a la materia (incluyendo el Título $\mathrm{V}$ de la Ley $\mathrm{N}^{\mathrm{o}} 13.305$ ) y no se dejaba expresamente subsistente;

5.5. La Ley $N^{o} 19.911$, de 14 de noviembre de 2003, eliminó totalmente el carácter penal de las conductas descritas en su artículo $3^{\circ}$, letra a), consistentes en impedir, restringir o entorpecer la libre competencia mediante acuerdos expresos o tácitos entre agentes económicos, o las prácticas concertadas entre ellos, que tengan por objeto fijar precios de venta o de compra;

atente contra la libre competencia en el mercado chileno.”. 
Polít. crim. Vol. 7, No 14 (Diciembre 2012), Art. 3, pp. 318 - 356.

[http://www.politicacriminal.cl/Vol_07/n_14/Vol7N14A3.pdf]

5.6. Debido a esta situación de falta de punibilidad de lo que se ha denominado como "colusión" para fijar precios, se discuten actualmente en el Congreso Nacional diversas mociones e indicaciones que pretenden "llenar ese vacío" y volver a considerar como punible al menos la conducta consistente en acordar precios de venta.

5.7. Por otra parte, es posible concluir que si "los acuerdos expresos o tácitos entre competidores, o las prácticas concertadas entre ellos, que tengan por objeto fijar precios de venta", hubiesen estado comprendidos en el artículo 285 del Código penal de 1874 (como sostienen algunas interpretaciones contrarias a su texto y a la historia de su establecimiento), ese artículo estaría en dicha parte derogado tácita y orgánicamente por la Ley $\mathrm{N}^{\mathrm{o}}$ 13.305, de $1959 \mathrm{y}$, si así no lo fuera, por la despenalización de tales hechos establecida expresamente por la Ley $\mathrm{N}^{\mathrm{o}} 19.911$, de 2003, cuyo objetivo, historia fidedigna y sentido objetivo son absolutamente incompatibles con la pretensión de que su despenalización en el siglo XXI signifique al mismo tiempo su penalización por una norma del siglo XIX, pues en la dogmática del "resurgimiento de la ley desplazada" no se admite éste cuando con ello se lleva a pasar la voluntad claramente manifestada por el legislador de despenalizar o establecer un privilegio.

5.8. Quienes, con todo, insistan en la punibilidad de los acuerdos de precios de conformidad con las disposiciones del Artículo 285 o 473 del Código penal, deberán, además, hacerse cargo del problema de ne bis in ídem que surge inmediatamente tras dicha afirmación, pues las multas gubernativas que a los particulares pueden imponerse "administrativamente" por los mismos hechos son cuantiosas y se imponen en un procedimiento ante un tribunal especial cuyo órgano acusador posee atribuciones muy similares a las del Ministerio Público. Un análisis detallado de esta cuestión supondría, no obstante, aceptar la conclusión que aquí se refuta, esto es, que los acuerdos de precio son punibles en Chile, lo cual rechazamos por los argumentos antes expuestos. 
MATUS, Jean Pierre. "Acerca de la actual falta de punibilidad en Chile de los acuerdos de precios".

\section{BIBLIOGRAFÍA}

Actas de las sesiones de la Comisión Redactora del Código penal chileno. Santiago: Imp. De la República de Jacinto Nuñez, 1873, 314 pp. encuadernadas junto al Proyecto de Código penal Chileno, de la misma imprenta y año.

ALESSANDRI R., Arturo; SOMARRIVA U., Manuel; VODANOVIC H., Antonio, Derecho Civil, T. I, Parte General y de las Personas, $2^{a}$ ed., Santiago: Ed. Nascimento, 1945.

BAÑADOS, Florencio, Código penal de la República de Chile concordado y comentado, Santiago: L. A. Lagunas, 1920.

BIBLIOTECA DEL CONGRESO NACIONAL, Historia de la Ley $N^{\circ} 13.305$.

BIBLIOTECA DEL CONGRESO NACIONAL, Historia de la Ley $N^{o} 19.911$, Crea el Tribunal de Defensa de la Libre Competencia. 14 de noviembre de 2003, 669 pp.

COUSIÑO M., Luis, "El delito socioeconómico", Revista de Ciencias Penales, T. XXI (1962), pp. 47-63, pp. 48-50, 59 y ss.

DEL RÍO, J. Raimundo. Derecho penal. Tercer tomo. Santiago: Nascimento, 1935, 580 pp.

DEPOLO RAZMILIC, Radoslav, "El régimen jurídico de defensa de la competencia en Chile. Algunas proposiciones para su despenalización". Revista de Derecho de la Universidad Católica de Valparaíso, t. XVIII (1997), pp. 435-441.

DOMPER, $\mathrm{M}^{\mathrm{a}}$ de la Luz; BUCHHEISTER, Axel, Tribunal de la Competencia: Modificaciones a la institucionalidad antimonopolio en Chile. Serie Informe Económico No 133. Santiago: Instituto Libertad y Desarrollo, 2002, 42 pp., p. 38.

ETCHEBERRY, Alfredo, Derecho penal, parte especial, t. IV. Tercera edición revisada y actualizada. Santiago: Ed. Jurídica de Chile, 1998, 382 pp.

FERNÁNDEZ, Pedro Javier, Código penal de la República de Chile, explicado $i$ concordado. Segunda Edición notablemente aumentada i corregida, t. II, Santiago: Imp. Barcelona, 1900, $410 \mathrm{pp}$.

FUENZALIDA, Alejandro, Concordancias i Comentarios del Código penal chileno, t. III. Lima: Imp. Comercial Calle del Haullaga N. 139, 1883, 372 pp.

GUZMÁN BRITO, Alejandro, "Codificación, descodificación y recodificación del Derecho civil en Chile", en Revista de Derecho y Jurisprudencia, TOMO XC (1993), $\mathrm{N}^{\mathrm{o}}$ 2, pp. 39-62 [en MICROJURIS: MJCH_MJD117 | RDJ 90-2-39]. HERNÁNDEZ, Héctor, "La punibilidad de la colusión (secreta) de precios en el derecho chileno", Polít. crim., Vol. 7, No 13 (Julio 2012), Artículo 4, pp. 147 - 167, en http://www.politicacriminal.cl/Vol 07/n 13/Vol7N13A4.pdf

LABATUT, Gustavo, Derecho penal, Tomo II, parte especial. Séptima edición. Actualizado por el profesor Julio Zenteno Vargas. Santiago: Editorial Jurídica de Chile, 1996, $263 \mathrm{pp}$.

MATUS A., Jean Pierre, "LLa teoría del concurso aparente de leyes penales y el "resurgimiento" de la ley en principio desplazada", en Revista de Derecho (U. Católica de Coquimbo), No 9 (2002), pp. 27-68. , El Concurso aparente de leyes, Santiago: Ed. Jurídicas de Santiago, 2008, pp. 122-124 y 273-277. 
Polít. crim. Vol. 7, No 14 (Diciembre 2012), Art. 3, pp. 318 - 356.

[http://www.politicacriminal.cl/Vol_07/n_14/Vol7N14A3.pdf]

MINISTERIO PÚBLICO, FISCALÍA NACIONAL, Reforma procesal penal. Oficios del Fiscal Nacional en materias penales. 2001-2004. Santiago: Ed. Jurídica de Chile, 2005, 488 pp.

NOVOA MONREAL, Eduardo, "La legislación penal económica". En: UNIVERSIDAD CATÓLICA DE CHILE. FACULTAD DE CIENCIAS JURÍDICAS, POLÍTICAS Y SOCIALES, La Nueva Legislación y el Desarrollo Económico de Chile. Ciclo de Conferencias, Julio-Septiembre, 1962. Santiago: Editorial Universidad Católica, 1962, 179 pp., pp. 151-177

ORTEGA, Leopoldo, "De la derogación de las leyes y especialmente de la derogación orgánica”, Revista de Derecho y Jurisprudencia, T. XXXV (1938), Primera Parte, pp. 6-12.

ORTÚZAR, Enrique, "Discurso del acto inaugural de las Quintas Jornadas de Ciencias Penales", Revista de Ciencias Penales, T. XXI (1962), pp. 6-10, p. 9.

PACHECO, Joaquín Francisco, El Código penal concordado y comentado, t. III, Madrid: Imp. Santiago Saunaque, 1849, 500 pp.

POLITOFF, Sergio; MATUS, Jean Pierre; RAMÍREZ, Ma Cecilia, Lecciones de Derecho penal chileno, parte especial, $2^{a}$ edición. Santiago: Ed. Jurídica de Chile, 2005, 689 pp.

SERRANO GÓMEZ, Alfonso; SERRANO MAÍLLO, Alfonso, Derecho penal, parte especial, $12^{a}$ edición. Madrid: Dykinson 2007, 1186 pp.

VARAS, Eduardo, "Discurso del acto inaugural de las Quintas Jornadas de Ciencias Penales", Revista de Ciencias Penales, T. XXI (1962), pp. 10-16, pp. 11, 13 y 14.

VERA, Robustiano, Código penal de la República de Chile, comentado. Santiago: Imprenta de P. Cadot i Cía., 1883, 840 pp. 